Prepared in cooperation with Anoka, Carver, Dakota, Hennepin, Ramsey, Scott, and Washington Counties and the Minnesota Board of Soil and Water Conservation

\title{
Estimates of Recharge to Unconfined Aquifers and Leakage to Confined Aquifers in the Seven-County Metropolitan Area of Minneapolis-St. Paul, Minnesota
}

Water-Resources Investigations Report 02-4092

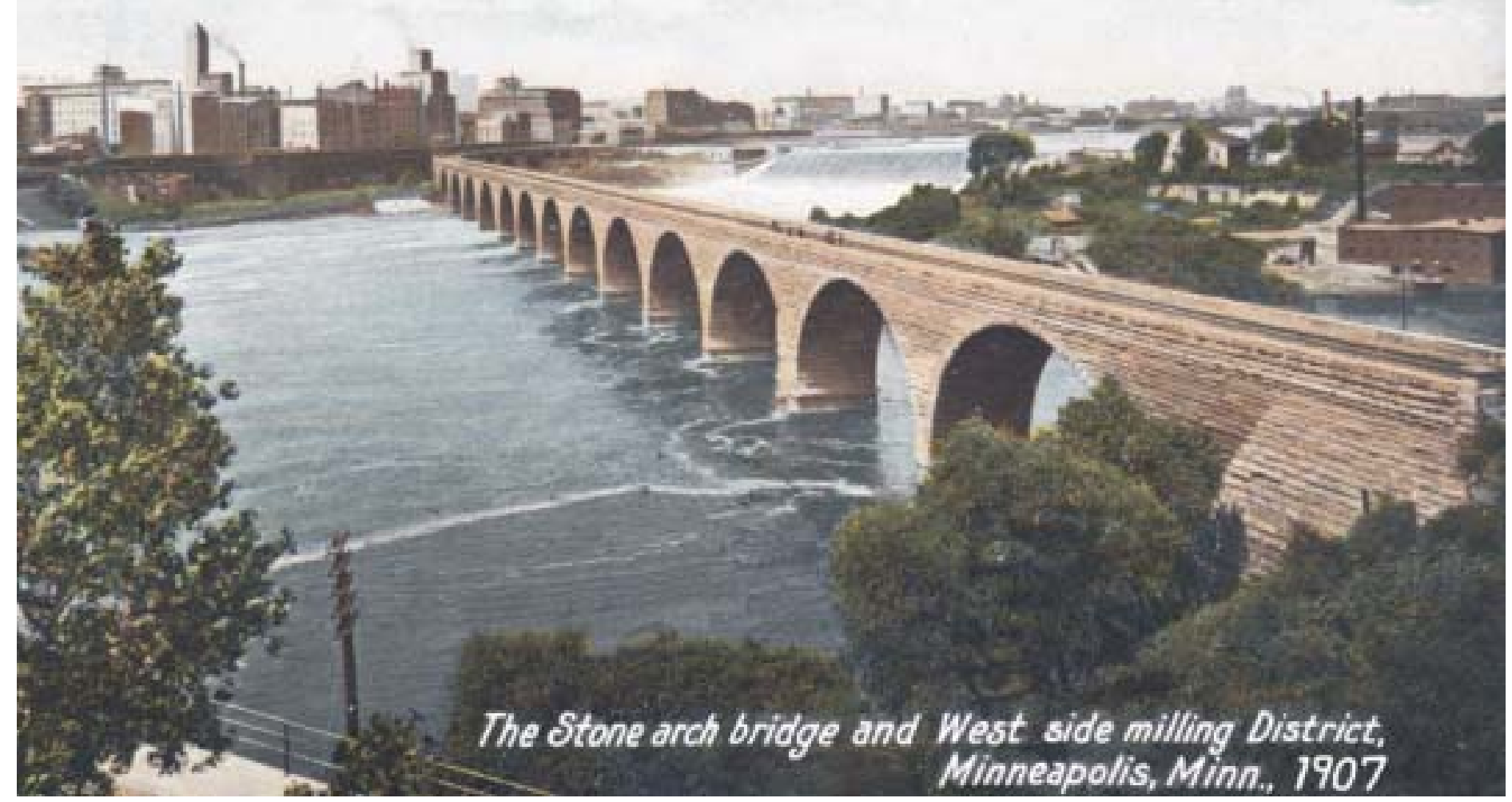

U.S. Department of the Interior

U.S. Geological Survey 



\section{Estimates of Recharge to Unconfined Aquifers and Leakage to Confined Aquifers in the Seven-County Metropolitan Area of Minneapolis-St. Paul, Minnesota}

By James F. Ruhl, U. S. Geological Survey, Roman Kanivetsky, Minnesota Geological Survey, and Boris Shmagin, Minnesota Geological Survey

Water-Resources Investigations Report 02-4092

Prepared in cooperation with Anoka, Carver, Dakota, Hennepin, Ramsey, Scott, and Washington Counties and the Minnesota Board of Soil and Water Conservation 


\title{
U.S. DEPARTMENT OF THE INTERIOR
}

\author{
Gale A. Norton, Secretary
}

\section{U.S. GEOLOGICAL SURVEY}

Charles G. Groat, Director

Use of brand names in this report is for identification purposes only and does not constitute endorsement by the U.S. Geological Survey.

Mound View, Minnesota, 2002

For additional information write to:

U.S. Geological Survey

District Chief

2280 Woodale Drive

Mounds View, MN 55112

Copies of this report can be purchased from:

\section{U.S. Geological Survey}

Branch of Information Services

Box 25286, MS 517

Federal Center

Denver, CO 80225

Information regarding the USGS is available on the Internet via the World Wide Web.

You may connect to the USGS Home Page using the Universal Resource Locator (URL) at http://www.rvares.er.usgs.gov

You may also connect to the Minnesota District Home Page at http://mn.water.usgs.gov/

For more information on all USGS reports and products (including maps, images, and computerized data), call 1-888-ASK-USGS

Water-Resources Investigations Report 02-4092 


\section{CONTENTS}

Abstract

Introduction.

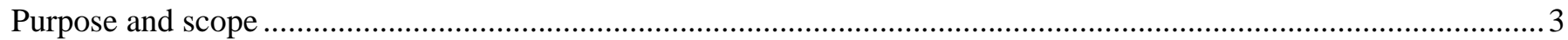

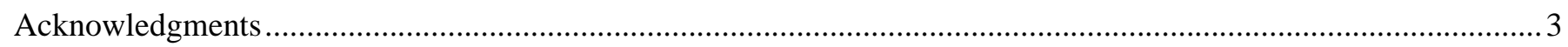

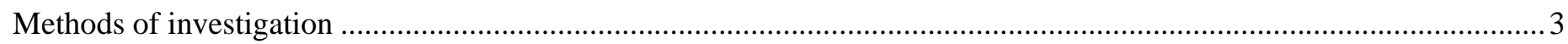

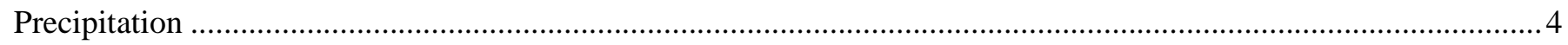

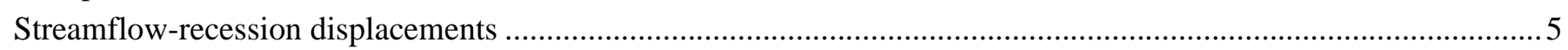

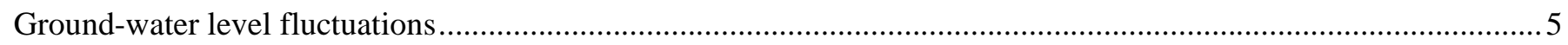

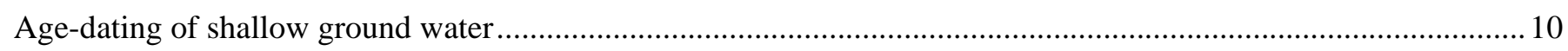

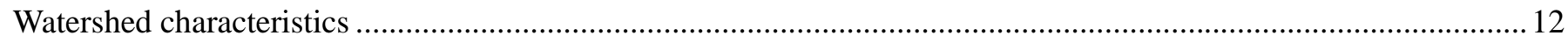

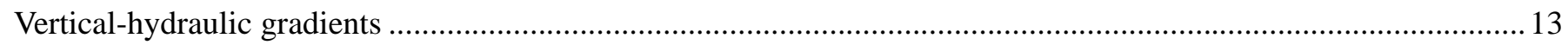

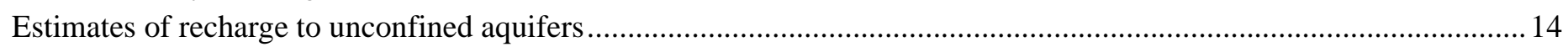

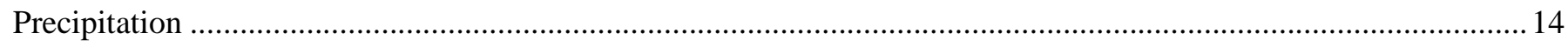

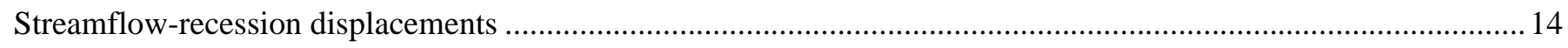

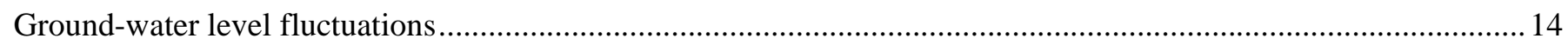

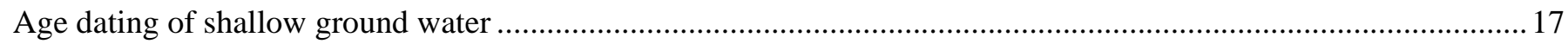

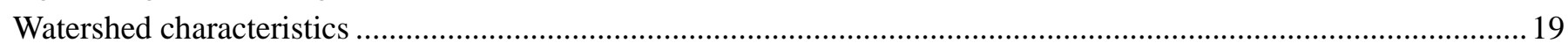

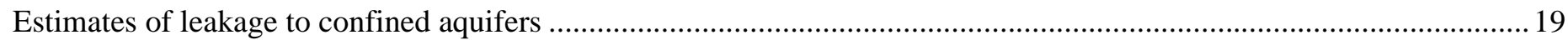

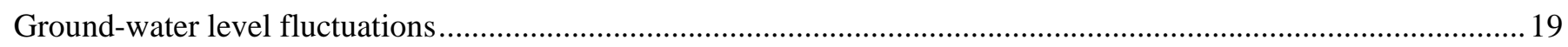

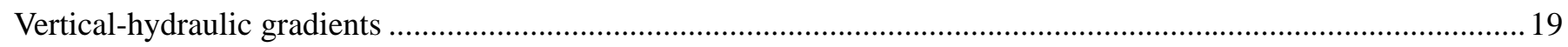

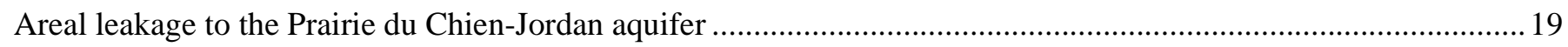

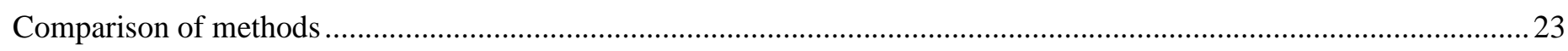

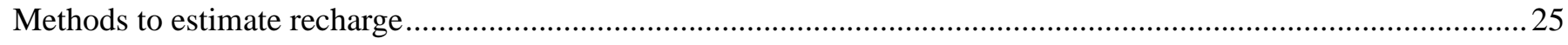

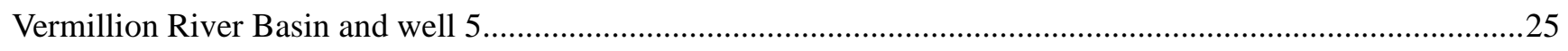

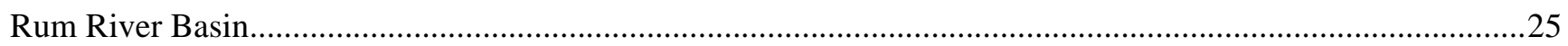

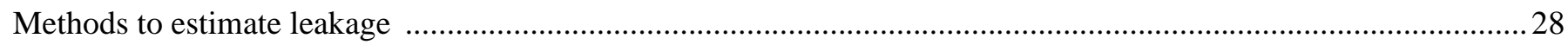

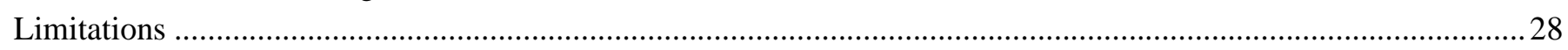

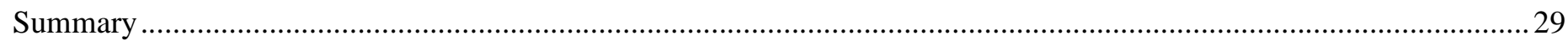

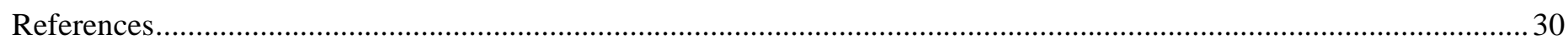

ILLUSTRATIONS

Figures 1-3 Maps showing:

1. Location of study area, basins, and data collection sites in the Twin Cities metropolitan study area, Minnesota

2. Areas of potential minimum and maximum recharge based on land-surface permeability in the

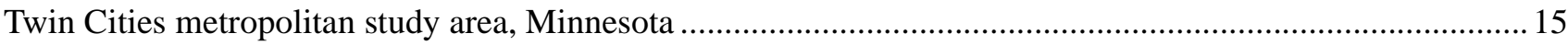

3. Recharge based on precipitation in the Twin Cities metropolitan study area, Minnesota ............................... 16

Figures 4-5 Diagrams showing:

4. Median annual recharge based on streamflow-recession displacements for 7 basins in the Twin Cities metropolitan study area, Minnesota.......

5. Median annual recharge based on ground-water level fluctuations for 11 wells in the Twin Cities metropolitan study area, Minnesota.

Figures 6-7 Maps showing:

6. Minimal ground-water recharge based on statistical analyses of watershed characteristics in the Twin Cities metropolitan study area, Minnesota. 


\section{ILLUSTRATIONS--CONTINUED}

7. Subcrops of principal bedrock formations that contain aquifers in the Twin Cities metropolitan study area, Minnesota...

Figures 8-9 Charts showing:

8. Leakage based on ground-water fluctuations for 11 wells in the Twin Cities metropolitan study area, Minnesota

9. Leakage based on vertical-hydraulic gradients for seven nested well sites in the Twin Cities metropolitan study area, Minnesota

Figure 10. Map showing leakage to the Prairie du Chien-Jordan aquifer based on vertical-hydraulic gradient method in the Twin Cities metropolitan study area, Minnesota

\section{TABLES}

1. Annual recharge estimated from streamflow-recession displacements for seven basins in the Twin Cities metropolitan study area, Minnesota.

2. Selected construction and hydrogeologic data for analyzed wells at 25 sites in the Twin Cities metropolitan study area, Minnesota

3. Annual recharge estimated from ground-water fluctuation method for 11 monitoring wells completed in unconfined glacial drift aquifers in the Twin Cities metropolitan study area, Minnesota.

4. Comparison of recharge and leakage estimates based on multiple methods in the Twin Cities metropolitan area, Minnesota.

\section{CONVERSION FACTORS}

\section{Multiply}

inch (in.)

foot (ft)

mile (mi)

inch per year (in./yr)

foot (ft/d)

square foot $\left(\mathrm{ft}^{2}\right)$

cubic foot per second $\left(\mathrm{ft}^{3} / \mathrm{s}\right)$

cubic foot per year $\left(\mathrm{ft}^{3} / \mathrm{yr}\right)$
By

2.54

0.3048

1.609

2.54

0.3048

0.09290

0.02832

0.02832
To obtain

centimeter

meter

kilometer

centimeter per year

meter per day

square meter

cubic meter per second

cubic meter per year

Sea level: In this report, "sea level" refers to the National Geodetic Vertical Datum of 1929 (NGVD of 1929). Geodetic datum is derived from a general adjustment of the first-order level nets of both the United States and Canada, formerly called Sea Level Datum of 1929. 


\section{Estimates of Recharge to Unconfined Aquifers and Leakage to Confined Aquifers in the Seven-County Metropolitan Area of Minneapolis-St. Paul, Minnesota}

\section{By James F. Ruhl, Roman Kanivetsky, and Boris Shmagin}

\section{ABSTRACT}

Recharge to unconfined aquifers in the seven-county Twin Cities metropolitan area of Minnesota was estimated by five methods. Mean recharge estimated as a percentage (27 percent) of precipitation ranged from 7.7 to $8.3 \mathrm{in./yr}$ across the study area. The median recharge estimated from automated analyses of streamflow-recession displacements for seven basins ranged from 1.2 to 12.2 in./yr. Median recharge estimated from graphical analyses of groundwater level fluctuations for 11 wells ranged from 4.5 to 13.6 in./yr. Recharge estimated by age dating of shallow ground water at a nested well site was $8.8 \mathrm{in} . / \mathrm{yr}$. Minimal ground-water recharge estimated by statistical analyses of watershed characteristics (geologic data and streamflow records) ranged from less than 0.1 to $5.6 \mathrm{in./yr}$.

Leakage, considered recharge to confined aquifers, in the seven-county Twin Cities metropolitan area was esti- mated by two methods. Leakage estimated by analyses of ground-water level fluctuations for 11 wells ranged from $3.2 \times 10^{-3}$ to $1.1 \times 10^{-2}$ in./yr. Leakage estimated by analyses of vertical-hydraulic gradients based on application of the Darcy flow equation for seven nested well sites ranged from $4.6 \times 10^{-5}$ to $1.1 \times 10^{-1} \mathrm{in} . / \mathrm{yr}$.

Recharge estimates, which generally varied within 10 in./yr for each of the methods, generally were largest based on the precipitation, ground-water level fluctuation, and age dating of shallow ground water methods, slightly smaller based on the streamflow-recession displacement method, and smallest based on the watershed characteristics method. Leakage, which was less than $1 \mathrm{in./yr}$, varied within 1 order of magnitude based on the ground-water level fluctuation method and as much as 4 orders of magnitude based on analyses of vertical-hydraulic gradients.

\section{INTRODUCTION}

The TCMA (Twin Cities metropolitan area) of Minneapolis and St. Paul, Minnesota (fig. 1) uses nearly one billion gallons of water per day for cooling power plants, commercial and industrial purposes, and household supplies (Metropolitan Council, 2000). Management of the water resources to supply these needs to the rapidly growing TCMA presents a long-term challenge for local government entities.

The sources of water supply for the TCMA include both surface and ground water. Surface-water resources in the TCMA include three major rivers-the Mississippi, the Minnesota, and the St. Croix. The Mississippi River provides about 75 percent of the water supply for the TCMA, and ground water provides the remainder. During the next 25 years, ground-water sources likely will increase to meet the expanded water needs of the TCMA generated by population growth and economic development.

Ground water in the TCMA is available from glacial-drift and bedrock aquifers (Schoenberg, 1990). The glacial-drift aquifers, which include both unconfined and confined units, consist of outwash and alluvium. The principal bedrock aquifers, which are contained in one or more hydrogeologic units, are (in descending order) the St. Peter, the Prairie du Chien-Jordan, the Ironton-Galesville (also includes the Franconia in some areas), and the Mt. Simon-Hinckley aquifers. These aquifers comprise both friable sandstone and fractured carbonate units. In the TCMA, the Prairie du Chien-Jordan is the predominant water-supply aquifer. Glacial-drift and bedrock confining units, depending on their areal extent, overlie these aquifers throughout most of the study area. Delin and Woodward (1982) and Runkel and Mossler (2001) provide detailed hydrogeologic descriptions of these aquifers and confining units.

As development of the TCMA continues, impervious land areas will increase from construction of roads, parking lots, and buildings. Regionally, proliferation of these areas likely will result in increased overland runoff and thereby decrease infiltration and replenishment of the ground- 


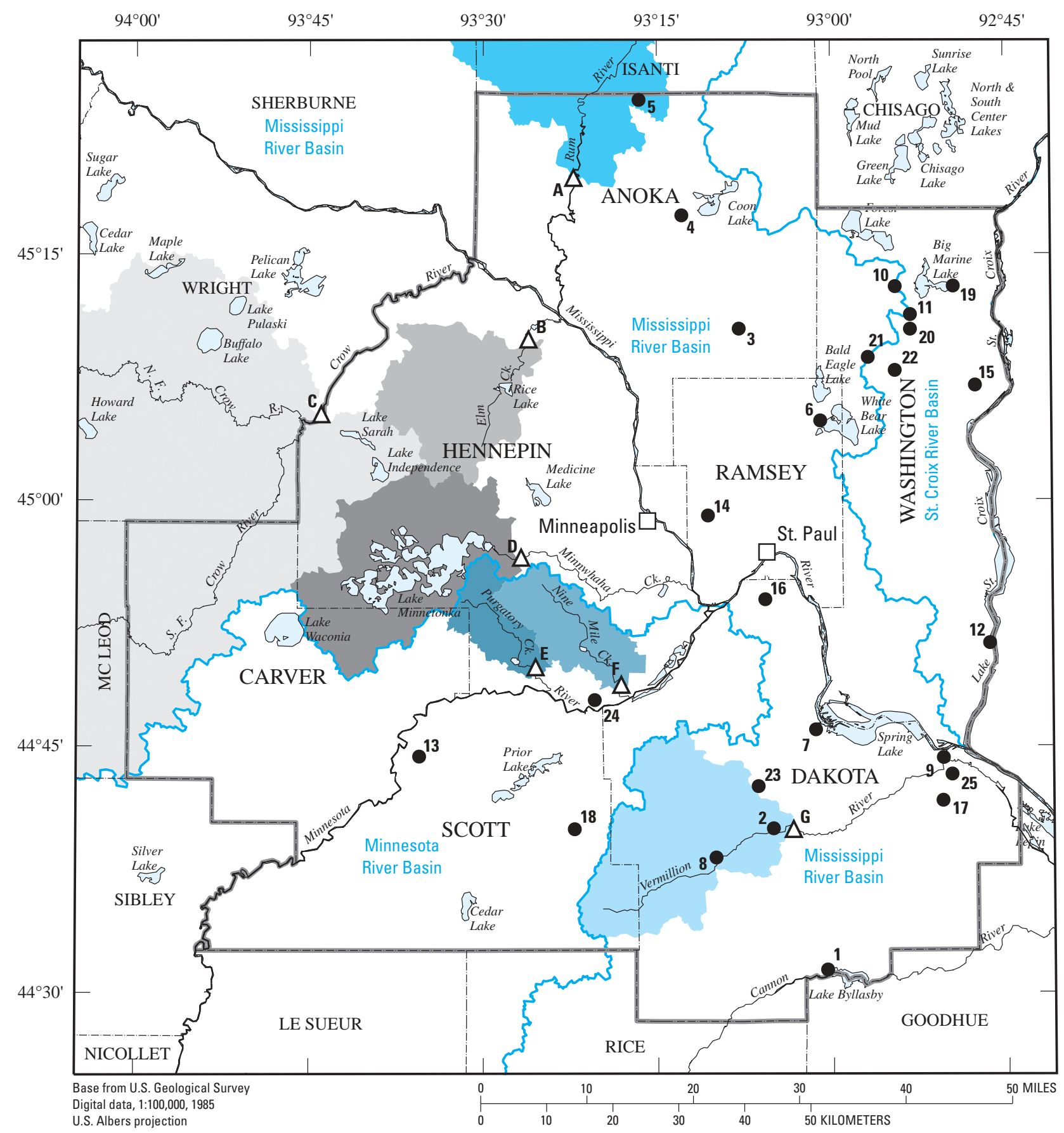

EXPLANATION

\section{Crow River Basin}

Elm Creek Basin

Minnehaha Creek Basin

Nine Mile Creek Basin

Purgatory Creek Basin

Rum River Basin

Vermillion River Basin

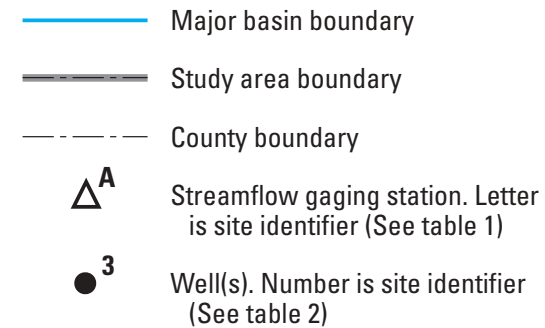

(See table 2)

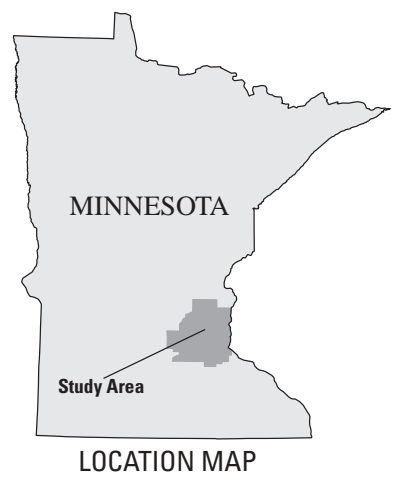

Figure 1. Location of study area, basins, and data collection sites in the Twin Cities metropolitan study area, Minnesota. 
water supply. Construction of storm sewer systems associated with urbanization will also contribute to increased runoff from rivers. Potential long-term volume reductions of the ground-water supply in the TCMA can be addressed with land-use practices such as maintenance or creation of drainage features that promote retention and infiltration of water from rainfall and snowmelt. Development of plans and policies to address these and other anticipated groundwater resource management issues will benefit from reliable estimates of ground-water recharge to shallow, unconfined aquifers and leakage to deep, confined aquifers.

The USGS (U.S. Geological Survey) conducted a three-year (19992001) study in the TCMA (hereinafter referred to as the study area). This study was done to estimate recharge to unconfined aquifers and leakage to confined aquifers in cooperation with the following seven countiesAnoka, Carver, Dakota, Hennepin, Ramsey, Scott, and Washington-and the Minnesota Board of Soil and Water Conservation. This study was done because reliable estimates of recharge and leakage are needed for: (1) development of wellhead protection programs; (2) determination of flushing rates for contaminated ground water; (3) delineation of contributing areas to wells designed to capture contaminated ground water; (4) evaluation of the role of recharge in the regional ground-water flow system; (5) accuracy in calibration of ground-water flow models; and (6) assessment of ground-water supply potential.

Recharge, as used in this report, is defined as the annual rate of water that enters the ground-water reservoir in unconfined aquifers at the watertable surface. If a simplified hydrogeologic system is assumed, changes in ground-water storage of this reservoir are small and additions attribut- able to recharge approximately balance losses attributable to groundwater discharge to surface waters, evapotranspiration to the atmosphere, and possibly withdrawals from wells. Leakage, as used in this report, is defined as the annual rate of water that enters confined aquifers attributable to vertical flow through confining units. Although this definition of leakage can be distinguished from the previously stated definition of recharge, leakage could be considered as recharge to confined, extensive aquifers in hydrogeologic settings such as that in the study area.

\section{PURPOSE AND SCOPE}

The purpose of this report is to present quantitative and qualitative estimates of recharge to unconfined aquifers and leakage to confined aquifers in the study area. The following methods used to make estimates are described in this report: (1) precipitation; (2) streamflow-recession displacements; (3) ground-water level fluctuations; (4) age-dating of shallow ground water; (5) watershed characteristics; and (6) vertical-hydraulic gradients. The report also compares results of the methods and evaluates their limitations.

Specific data included in this analysis include: (1) precipitation data from 150 rain gages; (2) streamflow hydrographs for 7 basins; (3) groundwater hydrographs for 27 wells; (4) concentrations of the environmental tracer, sulfur hexafluoride $\left(\mathrm{SF}_{6}\right)$, in ground-water samples from nested monitoring wells at 1 site; (5) hydrologic characteristics of 101 watersheds; and (6) vertical-hydraulic gradients at seven nested monitoring well sites. Interpretations of: (1) impervious areas based on satellite imagery data; (2) the areal extent of sand and gravel deposits based on surficial geologic maps; and (3) subcrops of principal aquifers based on bedrock geologic maps also are presented in this report.

\section{ACKNOWLEDGMENTS}

The authors thank the many people who contributed their time and talents to the preparation and completion of this report. Many of these people compiled and provided hydrologic and climatic data that were essential to application of the methods used to estimate recharge. Greg Spoden, State Climatologist, Minnesota Department of Natural Resources, provided, compiled, and analyzed precipitation data from monitoring stations throughout the State. Tom Gullett, hydrologist, Minnesota Department of Natural Resources, Division of Waters, provided well data for monitoring wells analyzed in the study. Richard Marsh, Environmental Specialist, Anoka County, assisted in ground-water-level data analyses and field-collection of ground-water samples for environmental tracer analyses. Bill Olsen and Emily Schneider of the Environmental Management Division of Dakota County provided historical water-quality data and access to a nested pair of Dakota County monitoring wells that were sampled for $\mathrm{SF}_{6}$ analyses. Dr. Marvin Bauer, professor in the College of Natural Resources, and Jean Doyle, an M.S. student in Water Resources Science, University of Minnesota, provided impervious-area-classification data for the study area.

\section{METHODS OF INVESTIGATION}

Multiple methods were used to quantitatively estimate recharge and leakage. These methods included precipitation, streamflow-recession displacements, ground-water level fluctuations, age-dating of shallow ground water, watershed characteristics, and vertical-hydraulic gradients. Except for the watershed-characteristics approach, these methods are standard approaches that have been widely used in a variety of hydrogeologic settings. The watershed charac- 
teristics method, which is still being researched, has been applied in Russia (Shmagin, 1997). The use of multiple methods is considered advantageous because of the opportunity presented to achieve consistent results. Achievement of consistent results, although not a guarantee of their accuracy, nevertheless strengthens the confidence level associated with their accuracy.

The methods used to estimate recharge and leakage in this study are comparatively evaluated in terms of expected accuracy, time and scale, ease of application, and data requirements. Differences in the time and scale associated with these methods, however, made direct comparisons difficult on a site-specific basis. Direct comparisons of results from different methods, therefore, are limited to selected sites and, if possible, are qualified with regard to time-scale differences.

A qualitative assessment of recharge was made on the basis of permeability of land-surface materials. Areas were mapped as surficial sand and gravel- these areas are considered to represent maximum permeability zones. These areas were delineated on the basis of glacial and post-glacial features shown on surficial geologic maps (Balaban and McSwiggen, 1982; Balaban, 1989; Swanson and Meyer, 1990; Balaban and Hobbs, 1990; Meyer and Swanson, 1992; Meyer and Patterson, 1999; and Meyer and Lusardi, 2000). Areas also were mapped greater than 75 percent impervious - areas that predominantly consist of roadways, parking lots, sidewalks, rooftops, buildings and other similar structures. These areas are considered to represent minimum permeability zones. These areas were delineated on the basis of interpretations of Landsat Thematic Mapper satellite imagery (J.K. Doyle, M.S. student, Water Resources Science, and M.E. Bauer, professor, College of Natural
Resources, University of Minnesota, written commun., 2000).

A qualitative assessment of leakage was made from mapped subcrops of principal bedrock aquifers. The subcrops of these aquifers, where the overlying materials only consist of glacial drift, are considered areas of greatest potential leakage, depending on the thickness and permeability of the overlying drift. Quantitative estimates of leakage were made from analyses of ground-water level fluctuations and vertical-hydraulic gradients.

\section{PRECIPITATION}

Precipitation data were analyzed to make small-scale estimates of recharge throughout the study area. In this method, recharge is estimated directly from precipitation based on a linear model that assumes recharge is equal to a specified percentage of precipitation. The time scale of the estimates is the period of record of the analyzed precipitation data.

Recharge as a percentage of precipitation has been reported to range from 4 to 70 percent (Puente, 1975, 1978; Delin and others, 1994; Snyder and others, 1994; Athavale and Rangarajan, 1997; Bauer and Mastin, 1997; and Delin and others, 2000). For the purposes of this study, percentages of 12,27 , and 44 percent were used as proportionality factors to compute recharge. These factors are based on results of the study by Delin and others (2000). The recharge rates associated with these factors $(12,27$, and 44 percent) represent minimum, mean, and maximum rates of recharge, respectively. The study by Delin and others (2000) was used as the basis to define these factors because of the proximity of that study area to the TCMA.

The study by Delin and others (2000) was conducted during 1992-95 in a surficial sand and gravel glacialoutwash aquifer at an agricultural research site located about 20 miles northwest of the study area. In that study, recharge was estimated by three methods: (1) ground-water level hydrograph analyses; (2) age-dating of shallow ground water based on chlorofluorocarbon environmental tracers; and (3) temporal changes in the water balance for the unsaturated zone. Recharge estimated by these methods generally ranged from about 10-40 percent of precipitation.

The precipitation data used to estimate recharge for this study consisted of mean annual rates for a 30-year period of record (1961-90). These rates were compiled from precipitation data collected from about 150 monitoring stations throughout Minnesota. Delineation of these rates was done by automated computer analysis (kriging), a process by which the precipitation data were interpolated and plotted at spatially distributed grid points (Greg Spoden, State Climatologist, Minnesota Department of Natural Resources, written commun., 1999). These spatially distributed precipitation rates were then multiplied by the proportionality factors to compute minimum, mean, and maximum annual recharge rates for the grid points. Isolines of minimum, mean, and maximum annual recharge rates (in./yr) were then computer-contoured for the study area.

The proportion of precipitation that contributes to recharge in a basin varies depending on the hydrogeologic and topographic setting. Recharge would be expected to be greater in areas of highly permeable surficial materials, such as sandy outwash, than in areas of lower permeability surficial materials, such as clayey till plains. Recharge would be greater in upland areas than in stream valleys, which typically are discharge areas.

The proportion of precipitation in a basin that contributes to recharge is large where the combined amounts of evapotranspiration and overland run- 
off are small, and is relatively small where the combined rates of evapotranspiration and overland runoff are large. The hydrogeologic setting of the study area described in this report is in a temperate climate with moderate rates of evapotranspiration and overland runoff. Thus, the proportion of precipitation that contributes to recharge in the study area would be expected to be moderate, as indicated by Delin and others (2000).

\section{STREAMFLOW-RECESSION DISPLACEMENTS}

The streamflow-recession displacement method was used to make recharge estimates based on analyses of streamflow records for the following basins: (1) Crow River; (2) Elm Creek; (3) Minnehaha Creek; (4) Vermillion River; (5) Rum River; (6) Nine Mile Creek; and (7) Purgatory Creek (fig. 1). Streamflow-gaging stations on each of these streams were instrumented for collection of stage data on a continual basis. Stage-discharge relations developed for each station were used to derive daily mean discharges. The periods of streamflow record for these basins ranged from 2 to 39 years during 1961-98 (table 1). The recharge estimates for this method represent single integrated values that do not indicate the spatial variation that would be expected in the basins. The time scale of this method is the streamflow period of record.

Using the streamflow-recession displacement method, recharge was estimated from individual peaks in streamflow records for gaged basins. This method of analysis is based on the change in total potential groundwater discharge as estimated at the critical time after a streamflow peak by extrapolation from the pre-peak to the post-peak recession periods (Rorabaugh, 1964; Daniel, 1976). A computer program has been developed that applies this method to long-term records (Rutledge, 1993).
Estimation of the ground-water component from streamflow records for the purpose of quantifying groundwater recharge has been studied for many years. Many of these studies analyzed recessions of streamflow hydrographs to determine the groundwater component of the streamflow. In some cases, the ground-water contribution to streamflow, commonly termed base flow, is assumed equal to ground-water recharge.

Many of the studies of groundwater recharge based on streamflow records assume a one-dimensional model of ground-water discharge into a stream from a contiguous, watertable aquifer (Rorabaugh, 1964). Application of this model requires the following simplifying assumptions regarding the hydrogeologic setting of the stream basin: (1) the stream fully penetrates the aquifer; (2) the aquifer is isotropic and homogeneous; (3) recharge to the aquifer is uniform throughout the basin; and (4) the bottom of the aquifer is underlain by a confining unit. Although local ground-water systems that discharge to streams generally do not fit these assumptions, recharge estimates based on this method still may be valid because the errors associated with the local variability of hydrogeologic features are likely to be averaged over areas of many square miles.

This study used the computer program RORA (Rutledge, 1993) to estimate recharge from streamflow data. This program measures displacements for streamflow hydrograph recessions that follow recharge events. Requirements for application of the program are that: (1) all or most of the groundwater storage in the basin discharges to a stream with a gaging station that accurately measures the streamflow at the downstream end of the basin; (2) regulation and diversion of the streamflow are insignificant; and (3) the assumption that the recharge from individual precipitation events is instantaneous and distributed throughout the basin.

The RORA program is completely automated except for entry of a userspecified recession index, which is determined from a semilogarithmic streamflow hydrograph. This index is the time (typically in days) for the ground-water discharge to recede by one log cycle after a specified time interval following the last streamflow peak (Rutledge, 1997). This index was determined by the program RECESS (Rutledge, 1993), a support program of RORA. The program RECESS uses a repetitive interactive procedure that selects multiple periods of streamflow recession when all flow can be considered ground-water discharge and the profile of the groundwater hydraulic head distribution can be considered nearly stable.

The number of estimates used to determine median annual recharge values varied annually based on the period of record of each analyzed basin. The Crow and Rum River Basins had the largest number of years for which recharge was estimated-every year (except one for the Crow River) during 1961-98. Minnehaha Creek Basin, in contrast, had the smallest number of years (2) for which recharge was estimated.

\section{GROUND-WATER LEVEL FLUCTUATIONS}

The ground-water level fluctuation method was used to estimate recharge for monitoring wells completed in unconfined (water-table) glacial-drift aquifers and to estimate leakage for monitoring wells completed in confined glacial-drift and bedrock aquifers. Nearly all the wells for which recharge or leakage estimates were made are part of the Minnesota Department of Natural Resources (DNR) monitoring well network. The frequency of water-level measurements ranged from monthly to bimonthly; water levels were not ana- 
Table 1. Annual recharge estimated from streamflow-recession displacements for seven basins in the Twin Cities metropolitan study area, Minnesota [all data reported in inches; --, no data; nc, not computed]

\begin{tabular}{|c|c|c|c|c|c|c|c|c|}
\hline Year & $\begin{array}{l}\text { Crow River Basin }{ }^{1} \\
(05280000, \text { site C) }\end{array}$ & $\begin{array}{l}\text { Elm Creek Basin } \\
(05287890, \text { site B) }\end{array}$ & $\begin{array}{c}\text { Minnehaha Creek } \\
\text { Basin } \\
(05289500, \text { site D) }\end{array}$ & $\begin{array}{c}\text { Nine Mile Creek } \\
\text { Basin } \\
(05330900, \text { site F })\end{array}$ & $\begin{array}{l}\text { Purgatory Creek } \\
\text { Basin } \\
(05330800, \text { site E) }\end{array}$ & $\begin{array}{l}\text { Rum River Basin } \\
(05286000, \text { site A) }\end{array}$ & $\begin{array}{l}\text { Vermillion River } \\
\text { Basin } \\
(05345000, \text { site G) }\end{array}$ & $\begin{array}{l}\text { Median annual } \\
\text { recharge by year } \\
\text { for the seven } \\
\text { basins }\end{array}$ \\
\hline 1961 & 0.7 & -- & -- & -- & -- & 1.9 & -- & 1.3 \\
\hline 1962 & 4.1 & -- & 4.0 & -- & -- & 3.7 & -- & 4.0 \\
\hline 1963 & 2.0 & -- & 1.7 & 2.7 & -- & 3.0 & -- & 2.4 \\
\hline 1964 & 0.8 & -- & -- & 2.4 & -- & 2.6 & -- & 2.4 \\
\hline 1965 & 7.9 & -- & -- & 11.0 & -- & 8.1 & -- & 8.1 \\
\hline 1966 & 3.6 & -- & -- & 4.9 & -- & 7.1 & -- & 4.9 \\
\hline 1967 & 2.3 & -- & -- & 5.2 & -- & 5.2 & -- & 5.2 \\
\hline 1968 & 2.2 & -- & -- & 7.5 & -- & 5.6 & -- & 5.6 \\
\hline 1969 & 5.6 & -- & -- & 4.3 & -- & 6.1 & -- & 5.6 \\
\hline 1970 & 2.0 & -- & -- & 5.5 & -- & 3.1 & -- & 3.1 \\
\hline 1971 & 5.9 & -- & -- & 7.0 & -- & 5.5 & -- & 5.9 \\
\hline 1972 & 7.6 & -- & -- & 5.4 & -- & 9.7 & -- & 7.6 \\
\hline 1973 & 4.1 & -- & -- & -- & -- & 7.0 & -- & 5.5 \\
\hline 1974 & 2.5 & -- & -- & -- & -- & 5.5 & 3.5 & 3.5 \\
\hline 1975 & 3.9 & -- & -- & -- & -- & 6.2 & 5.7 & 5.7 \\
\hline 1976 & 1.8 & -- & -- & -- & 2.4 & 3.7 & 3.1 & 2.8 \\
\hline 1977 & 1.3 & -- & -- & -- & 2.9 & 3.5 & 2.6 & 2.7 \\
\hline 1978 & 4.5 & -- & -- & -- & 5.4 & 4.7 & 3.7 & 4.6 \\
\hline 1979 & 6.2 & 3.7 & -- & -- & 5.9 & 7.9 & 5.7 & 5.9 \\
\hline 1980 & 1.7 & 2.5 & -- & -- & 2.9 & 4.0 & 4.4 & 2.9 \\
\hline 1981 & 2.8 & 1.4 & -- & -- & -- & 4.3 & 3.6 & 3.2 \\
\hline 1982 & 6.5 & 4.4 & -- & -- & -- & 7.2 & 5.5 & 6.0 \\
\hline 1983 & 7.4 & 6.3 & -- & -- & -- & 7.0 & 8.4 & 7.2 \\
\hline 1984 & 10.1 & 7.1 & -- & -- & -- & 9.4 & 8.5 & 8.9 \\
\hline 1985 & 9.2 & 9.8 & -- & -- & -- & 8.8 & 6.6 & 9.0 \\
\hline 1986 & 13.4 & 9.1 & -- & -- & -- & 13.5 & 11.0 & 12.2 \\
\hline 1987 & 1.5 & 1.5 & -- & -- & -- & 3.7 & 4.3 & 2.6 \\
\hline 1988 & 0.7 & 0.5 & -- & -- & -- & 1.8 & 2.9 & 1.2 \\
\hline 1989 & 0.8 & 1.3 & -- & -- & -- & 2.1 & 4.1 & 1.7 \\
\hline 1990 & 2.4 & 3.7 & -- & -- & -- & 4.3 & 4.1 & 3.9 \\
\hline 1991 & 10.2 & 10.4 & -- & -- & -- & 7.1 & 4.6 & 8.6 \\
\hline 1992 & 6.5 & 5.4 & -- & -- & -- & 4.0 & 10.1 & 6.0 \\
\hline 1993 & 10.8 & 11.1 & -- & -- & -- & 5.7 & 13.1 & 10.9 \\
\hline 1994 & 6.1 & 6.2 & -- & -- & -- & 5.8 & 8.8 & 6.1 \\
\hline 1995 & 7.0 & 6.9 & -- & -- & -- & 7.8 & 7.8 & 7.4 \\
\hline 1996 & 4.8 & 6.1 & -- & -- & -- & 5.3 & 7.7 & 5.7 \\
\hline 1997 & 8.7 & 5.5 & -- & -- & -- & 5.4 & 10.9 & 7.1 \\
\hline 1998 & -- & -- & -- & -- & -- & 3.4 & 13.4 & 8.4 \\
\hline Mean annual recharge ${ }^{2}$ & 4.8 & 5.4 & 2.9 & 5.6 & 3.9 & 5.5 & 6.6 & $\mathrm{nc}$ \\
\hline Median annual recharge $^{2}$ & 4.1 & 5.5 & 2.9 & 5.3 & 2.9 & 5.4 & 5.7 & $\mathrm{nc}$ \\
\hline Mean annual runoff ${ }^{2}$ & 5.2 & 5.9 & 3.0 & 6.4 & 4.9 & 6.8 & 7.3 & $\mathrm{nc}$ \\
\hline
\end{tabular}

${ }^{1}$ Shown on figure 1

${ }^{2}$ For period of record 
lyzed when the frequency of measurements was greater than bimonthly.

Site-specific estimates of recharge were made for 11 monitoring wells (identified as wells 1-11, fig. 1, and table 2) completed in unconfined glacial-drift aquifers. For recharge estimates, the ground-water level fluctuation method was based on analyses of ground-water level hydrographs of the wells and the specific yield (the ratio of the volume of water that will drain under the influence of gravity from saturated, unconfined aquifer material to the volume of that material) of the aquifers in which the wells are completed (Rasmussen and Andreason, 1959; Delin and others, 1994).

The estimates made by this method are for localized areas surrounding the analyzed wells. The time scale of the estimates is the period of record of the hydrographs. To apply the method, each ground-water level rise is converted to an equivalent increase in ground-water storage considered to have been attributed to recharge. This method assumes that recharge from a given precipitation event is equal to the magnitude of the associated water-level rise multiplied by the specific yield, which typically ranges from 0.1 to 0.3 for water-table aquifers (Heath, 1983).

The graphical procedures used to analyze ground-water level data by this method are to extend each hydrograph recession based on its slope to the date of the next hydrograph peak. The recessions are extended to account for the additional amount of water-level decline that would have occurred without the succeeding recharge event. The estimated recharge for an individual precipitation event, therefore, is based on the difference between the peak water level and the extrapolated water level determined from the projected extension of the preceding water-level recession.
Recharge estimated by this method would be inaccurate if changes in ground-water levels were influenced by withdrawals from wells. Some investigators have reported that use of a single value of specific yield may result in overestimation of recharge in some hydrogeologic settings because of capillary fringe effects and hysteresis (Sophocleous, 1985). An unconfined aquifer with fine-grained sediments and shallow water table would be a setting where these factors could be significant.

Specific yields of 0.23 and 0.27 were used in this study to compute recharge estimates. These values are within the range of average specific yields reported by Fetter (1988) for fine to coarse sand, the general lithologic description of materials in which the analyzed monitoring wells were completed. In wells identified as 2-6 (fig. 1), the depth to water generally was less than $10 \mathrm{ft}$, so the lower specific yield of 0.23 was used to correct for potential overestimation of recharge attributable to capillary fringe effects and hysteresis. For all other wells completed in unconfined aquifers, the depth to water was greater than 10 feet and a specific yield of 0.27 was used.

The periods of record of the wells completed in unconfined aquifers ranged from 6 to 29 years during 1971-99 (table 3). Wells identified as 3 and 4 had the largest number of years for which recharge estimates were made-every year (except one for well 4) during 1971-99. Wells identified as 6 and 8 , in contrast, had the smallest number of years for which recharge estimates were made -6 and 7, respectively.

Leakage also was estimated by the ground-water level fluctuation method for 11 monitoring wells (identified as $15,15 \mathrm{~A}, 15 \mathrm{~B}$, and $17-24$, fig. 1 , and table 2) completed in confined glacial-drift and bedrock aquifers. These estimates were made from hydrographs of the wells in a manner nearly identical to that used to estimate recharge. An important difference, however, was that leakage to a confined aquifer was assumed equal to the associated water-level rise multiplied by the aquifer storage coefficient, rather than specific yield. The time scale of these leakage estimates, as was the case for recharge estimates, was the period of record of the analyzed hydrographs.

Hydrographs for wells completed in confined aquifers in the study area typically exhibit fluctuations caused by pumping of nearby wells. Most high-capacity supply wells in the study area are completed in confined bedrock aquifers, particularly the Prairie du Chien-Jordan aquifer. Withdrawals from these wells produce extensive cones of depression because of the confined conditions associated with these aquifers, and as a consequence, affect other nearby wells. For this reason, analyses were limited to hydrographs of 11 wells that generally were not influenced by pumping of nearby wells.

This study assumed that the confined aquifers in which the analyzed wells were completed had a storage coefficient of $1.0 \times 10^{-4}$. This value is within the range of $1.0 \times 10^{-5}$ to $1.0 \times 10^{-3}$ that typifies most confined aquifers (Heath, 1983). Strobel and Delin (1996) and Ruhl (1999) both reported storage coefficients within this range. These values were determined from aquifer tests of the Prairie du Chien-Jordan aquifer conducted in the southwestern part of the study area.

The periods of record of the wells analyzed to estimate leakage ranged from 3 to 21 years during 1971-99. Each of the hydrographs for these wells exhibited at least one extended period (6 months or more) of consistent water-level rise and recession without obvious pumping effects. Leakage was estimated from the rates 
Table 2. Selected construction and hydrogeologic data for analyzed wells at 25 sites in the Twin Cities metropolitan study area, Minnesota [ND, no data; NA, not applicable; --, same as preceeding; ft, feet;

\begin{tabular}{|c|c|c|c|c|c|c|c|c|c|}
\hline \multirow[b]{2}{*}{$\begin{array}{l}\text { Well identifier } \\
\text { (site shown on } \\
\text { figure 1) }\end{array}$} & \multirow[b]{2}{*}{ Location } & \multirow[b]{2}{*}{$\begin{array}{c}\text { Minnesota } \\
\text { unique } \\
\text { number }\end{array}$} & \multicolumn{4}{|c|}{ Well construction data } & \multicolumn{3}{|c|}{ Hydrogeologic data } \\
\hline & & & $\begin{array}{l}\text { Well depth (ft } \\
\text { below land } \\
\text { surface) }\end{array}$ & $\begin{array}{l}\text { Bottom of } \\
\text { casing } \\
\text { depth (ft) }\end{array}$ & $\begin{array}{c}\text { Screen } \\
\text { interval } \\
(\mathrm{ft})\end{array}$ & $\begin{array}{l}\text { Open- } \\
\text { hole } \\
\text { (ft) }\end{array}$ & $\begin{array}{c}\text { General } \\
\text { lithologic } \\
\text { description }\end{array}$ & $\begin{array}{l}\text { Depth to top } \\
\text { of lithologic } \\
\text { unit (ft) }\end{array}$ & $\begin{array}{c}\text { Depth to } \\
\text { bottom } \\
\text { (ft) }\end{array}$ \\
\hline \multirow[t]{5}{*}{1} & T112NR18WSEC08 & 243738 & 45 & 42 & 3 & NA & Fill & 0 & 2 \\
\hline & & & & & & & Sand & 2 & 47 \\
\hline & & & & & & & Gravel & 47 & 51 \\
\hline & & & & & & & Clay & 51 & 52 \\
\hline & & & & & & & Dolomite & 52 & ND \\
\hline \multirow[t]{2}{*}{2} & T114NR19WSEC22 & 243744 & 22 & 19 & 3 & NA & Soil & 0 & 2 \\
\hline & & & & & & & Sand & 2 & 22 \\
\hline 3 & T031NR22WSEC18 & 243470 & 13 & 11 & 2 & NA & Soil & 0 & 7 \\
\hline $3 \mathrm{~A}$ & -- & 208135 & 125 & 120 & 5 & NA & Sand & 7 & 40 \\
\hline 3B & -- & 208137 & 270 & 260 & 10 & NA & Clay & 40 & 90 \\
\hline \multirow[t]{5}{*}{$3 \mathrm{C}$} & -- & 208136 & 214 & 209 & 5 & NA & Clay & 90 & 125 \\
\hline & & & & & & & Clay & 125 & 208 \\
\hline & & & & & & & Gravel & & \\
\hline & & & & & & & Gravel & 208 & 270 \\
\hline & & & & & & & Sandstone & 270 & 280 \\
\hline 4 & T032NR23WSEC04 & 243471 & 21 & 19 & 2 & NA & Sand & 0 & 23 \\
\hline \multirow[t]{2}{*}{5} & T034NR24WSEC25 & 243479 & 21 & 19 & 2 & NA & Soil & 0 & 2 \\
\hline & & & & & & & Sand & 2 & 22 \\
\hline 6 & T030NR22WSEC23 & 227977 & 46 & 43 & 3 & NA & Sand & 0 & 42 \\
\hline \multirow[t]{7}{*}{$6 \mathrm{~A}$} & -- & 481807 & 226 & 222 & 4 & NA & Gravel & 42 & 46 \\
\hline & & & & & & & Clay & 46 & 48 \\
\hline & & & & & & & Sand & 48 & 94 \\
\hline & & & & & & & Clay & 94 & 95 \\
\hline & & & & & & & Sand & 95 & 196 \\
\hline & & & & & & & Dolomite & 196 & 225 \\
\hline & & & & & & & Sandstone & 225 & 226 \\
\hline \multirow[t]{2}{*}{7} & T115NR18WSEC18 & 243746 & 189 & 187 & 2 & NA & Sand & 0 & 188 \\
\hline & & & & & & & Sandy clay & 188 & 189 \\
\hline \multirow[t]{6}{*}{8} & T114NR20WSEC36 & 175910 & 81 & 61 & 20 & NA & Soil & 0 & 2 \\
\hline & & & & & & & Sand & 2 & 12 \\
\hline & & & & & & & Gravel & 12 & 35 \\
\hline & & & & & & & Sandy Clay & 35 & 37 \\
\hline & & & & & & & Sand & 37 & 54 \\
\hline & & & & & & & Gravel & 54 & 82 \\
\hline \multirow[t]{6}{*}{9} & T115NR17WSEC27 & 243778 & 29.5 & 25 & 5 & NA & Sand & 0 & 5 \\
\hline & & & & & & & Gravel & 5 & 9 \\
\hline & & & & & & & Sand & 9 & 12 \\
\hline & & & & & & & Sandy clay & 12 & 13 \\
\hline & & & & & & & Sand & 13 & 82 \\
\hline & & & & & & & Clay & 82 & 127 \\
\hline \multirow[t]{2}{*}{10} & T032NR21WSEC36 & 244594 & 27 & ND & ND & NA & Soil & 0 & 3 \\
\hline & & & & & & & Gravel & 3 & 27 \\
\hline \multirow[t]{3}{*}{11} & T031NR20WSEC07 & 244595 & 47 & ND & ND & NA & Soil & 0 & 3 \\
\hline & & & & & & & Sand & 3 & 20 \\
\hline & & & & & & & Sandy clay & 20 & 47 \\
\hline 12 & T027NR20WSEC02 & 216162 & 385 & 365 & NA & 20 & Sand & 0 & 5 \\
\hline \multirow[t]{5}{*}{$12 \mathrm{~A}$} & -- & 216161 & 535 & 530 & NA & 5 & Gravel & 5 & 46 \\
\hline & & & & & & & Sandstone & 46 & 90 \\
\hline & & & & & & & Siltstone & 90 & 105 \\
\hline & & & & & & & Sandstone & 105 & 115 \\
\hline & & & & & & & Siltstone & 115 & 125 \\
\hline
\end{tabular}


Table 2. Selected construction and hydrogeologic data for analyzed wells at 25 sites in the Twin Cities metropolitan study area, Minnesota (Continued)

\begin{tabular}{|c|c|c|c|c|c|c|c|c|c|}
\hline \multirow[b]{2}{*}{$\begin{array}{l}\text { Well identifier } \\
\text { (site shown on } \\
\text { figure 1) }\end{array}$} & \multirow[b]{2}{*}{ Location } & \multirow[b]{2}{*}{$\begin{array}{c}\text { Minnesota } \\
\text { unique } \\
\text { number }\end{array}$} & \multicolumn{4}{|c|}{ Well construction data } & \multicolumn{3}{|c|}{ Hydrogeologic data } \\
\hline & & & $\begin{array}{l}\text { Well depth (ft } \\
\text { below land } \\
\text { surface) }\end{array}$ & $\begin{array}{l}\text { Bottom of } \\
\text { casing } \\
\text { depth }(\mathrm{ft})\end{array}$ & $\begin{array}{c}\text { Screen } \\
\text { interval } \\
(\mathrm{ft})\end{array}$ & $\begin{array}{l}\text { Open- } \\
\text { hole } \\
(\mathrm{ft})\end{array}$ & $\begin{array}{c}\text { General } \\
\text { lithologic } \\
\text { description }\end{array}$ & $\begin{array}{l}\text { Depth to top } \\
\text { of lithologic } \\
\text { unit (ft) }\end{array}$ & $\begin{array}{l}\text { Depth to } \\
\text { bottom } \\
(\mathrm{ft})\end{array}$ \\
\hline \multirow[t]{8}{*}{ 12A-continued } & & & & & & & Sandstone & 125 & 163 \\
\hline & & & & & & & Siltstone & 163 & 167 \\
\hline & & & & & & & Sandstone & 167 & 175 \\
\hline & & & & & & & Shale & 175 & 330 \\
\hline & & & & & & & Sandstone & 330 & 385 \\
\hline & & & & & & & Shale & 385 & 394 \\
\hline & & & & & & & Sandstone & 394 & 485 \\
\hline & & & & & & & Sandstone & 485 & 560 \\
\hline 13 & T115NR23WSEC28 & 244436 & 140 & 75 & NA & 65 & Sand silt & 0 & 30 \\
\hline \multirow[t]{5}{*}{$13 \mathrm{~A}$} & -- & 244437 & 355 & 350 & NA & 5 & And gravel & & \\
\hline & & & & & & & Sandstone & 30 & 140 \\
\hline & & & & & & & Dolomite & 140 & 180 \\
\hline & & & & & & & Sandstone & 180 & 320 \\
\hline & & & & & & & Sandstone & 320 & 390 \\
\hline 14 & T029NR23WSEC21 & ND & 567 & 564 & 3 & NA & Sand Silt & 0 & 158 \\
\hline $14 \mathrm{~A}$ & -- & ND & 780 & 777 & 3 & NA & And gravel & & \\
\hline \multirow[t]{10}{*}{$14 \mathrm{~B}$} & -- & ND & 914 & 912 & 3 & NA & Limestone & 158 & 187 \\
\hline & & & & & & & Shale & 187 & 190 \\
\hline & & & & & & & Sandstone & 190 & 351 \\
\hline & & & & & & & Dolomite & 351 & 483 \\
\hline & & & & & & & Sandstone & 483 & 578 \\
\hline & & & & & & & Siltstone Shale & 578 & 601 \\
\hline & & & & & & & $\begin{array}{l}\text { Sandstone Silt- } \\
\text { stone Shale }\end{array}$ & 601 & 735 \\
\hline & & & & & & & Sandstone & 735 & 804 \\
\hline & & & & & & & Siltstone Shale & 804 & 899 \\
\hline & & & & & & & Sandstone & 899 & ND \\
\hline 15 & T030N20WSEC03 & 227033 & 130 & 126 & 4 & NA & Sand & 0 & 3 \\
\hline $15 \mathrm{~A}$ & -- & 227032 & 252 & 249 & 3 & NA & Clay & 3 & 6 \\
\hline \multirow[t]{9}{*}{$15 \mathrm{~B}$} & -- & 227031 & 360 & 303 & NA & 57 & Sand & 6 & 55 \\
\hline & & & & & & & Clay & 55 & 76 \\
\hline & & & & & & & Gravel & 76 & 134 \\
\hline & & & & & & & Clay & 134 & 160 \\
\hline & & & & & & & Sand & 160 & 170 \\
\hline & & & & & & & Clay & 170 & 180 \\
\hline & & & & & & & Gravel & 180 & 296 \\
\hline & & & & & & & Shale & 296 & 330 \\
\hline & & & & & & & Sandstone & 330 & 360 \\
\hline 16 & T028NR22WSEC19 & ND & 55 & 53 & 2 & NA & Gravel & 0 & 135 \\
\hline $16 \mathrm{~A}$ & -- & ND & 390 & 250 & NA & 140 & Sand & 135 & 196 \\
\hline \multirow[t]{8}{*}{$16 \mathrm{~B}$} & -- & ND & 652 & 561 & NA & 91 & Clay & 196 & 203 \\
\hline & & & & & & & Shale & 203 & 213 \\
\hline & & & & & & & Limestone & 213 & 239 \\
\hline & & & & & & & Shale & 239 & 245 \\
\hline & & & & & & & Sandstone & 245 & 402 \\
\hline & & & & & & & Dolomite & 402 & 539 \\
\hline & & & & & & & Sandstone & 539 & 624 \\
\hline & & & & & & & Shale & 624 & 652 \\
\hline \multirow[t]{3}{*}{17} & T114NR17WSEC10 & 243739 & 302 & 298 & 4 & NA & Sand Silt & 0 & 298 \\
\hline & & & & & & & And clay & & \\
\hline & & & & & & & Dolomite & 298 & 302 \\
\hline \multirow[t]{2}{*}{18} & T114NR21WSEC20 & 276759 & 98 & 93 & 5 & NA & Clay & 0.0 & 5.0 \\
\hline & & & & & & & Sand & 5.0 & 30.0 \\
\hline
\end{tabular}


Table 2. Selected construction and hydrogeologic data for analyzed wells at 25 sites in the Twin Cities metropolitan study area, Minnesota (Continued)

\begin{tabular}{|c|c|c|c|c|c|c|c|c|c|}
\hline \multirow[b]{2}{*}{$\begin{array}{l}\text { Well identifier } \\
\text { (site shown on } \\
\text { figure } 1 \text { ) }\end{array}$} & \multirow[b]{2}{*}{ Location } & \multirow[b]{2}{*}{$\begin{array}{c}\text { Minnesota } \\
\text { unique } \\
\text { number }\end{array}$} & \multicolumn{4}{|c|}{ Well construction data } & \multicolumn{3}{|c|}{ Hydrogeologic data } \\
\hline & & & $\begin{array}{l}\text { Well depth (ft } \\
\text { below land } \\
\text { surface) }\end{array}$ & $\begin{array}{l}\text { Bottom of } \\
\text { casing } \\
\text { depth }(\mathrm{ft})\end{array}$ & $\begin{array}{c}\text { Screen } \\
\text { interval } \\
(\mathrm{ft})\end{array}$ & $\begin{array}{l}\text { Open- } \\
\text { hole } \\
(\mathrm{ft})\end{array}$ & $\begin{array}{c}\text { General } \\
\text { lithologic } \\
\text { description }\end{array}$ & $\begin{array}{l}\text { Depth to top } \\
\text { of lithologic } \\
\text { unit (ft) }\end{array}$ & $\begin{array}{l}\text { Depth to } \\
\text { bottom } \\
\text { (ft) }\end{array}$ \\
\hline \multirow[t]{3}{*}{ 18-continued } & & & & & & & Clay & 30.0 & 50.0 \\
\hline & & & & & & & Sand & 50.0 & 98.0 \\
\hline & & & & & & & Dolomite & 98.0 & 99.0 \\
\hline \multirow[t]{6}{*}{19} & T032NR20WSEC34 & 195728 & 125 & 122 & 3 & NA & Soil & 0.0 & 3.0 \\
\hline & & & & & & & Clay & 3.0 & 32.0 \\
\hline & & & & & & & Sand & 32.0 & 55.0 \\
\hline & & & & & & & Clay & 55.0 & 67.0 \\
\hline & & & & & & & Sand & 67.0 & 110.0 \\
\hline & & & & & & & Sandstone & 110.0 & 125.0 \\
\hline \multirow[t]{5}{*}{20} & T031NR20WSEC18 & 195689 & 106 & 103 & 3 & NA & Soil & 0.0 & 3.0 \\
\hline & & & & & & & Sand & 3.0 & 69.0 \\
\hline & & & & & & & Clay & 69.0 & 72.0 \\
\hline & & & & & & & Sand & 72.0 & 95.0 \\
\hline & & & & & & & Dolomite & 95.0 & 106.0 \\
\hline \multirow[t]{7}{*}{21} & T031NR21WSEC27 & 195736 & 145 & 142 & 3 & NA & Soil & 0.0 & 3.0 \\
\hline & & & & & & & Clay & 3.0 & 78.0 \\
\hline & & & & & & & Sand & 78.0 & 87.0 \\
\hline & & & & & & & Sandstone & 87.0 & 105.0 \\
\hline & & & & & & & Clay & 105.0 & 120.0 \\
\hline & & & & & & & Gravel & 120.0 & 137.0 \\
\hline & & & & & & & Dolomite & 137.0 & 145.0 \\
\hline \multirow[t]{4}{*}{22} & T031NR21WSEC36 & 551565 & 148 & 130 & NA & 18 & Clay & 0 & 63 \\
\hline & & & & & & & Sand & 63 & 80 \\
\hline & & & & & & & Clay & 80 & 105 \\
\hline & & & & & & & Dolomite & 105 & 148 \\
\hline \multirow[t]{7}{*}{23} & T114NR19WSEC04 & 207608 & 415 & 355 & NA & 60 & Soil & 0.0 & 2.0 \\
\hline & & & & & & & Sand & 2.0 & 72.0 \\
\hline & & & & & & & Sand and gravel & 72.0 & 120.0 \\
\hline & & & & & & & Shale & 120.0 & 130.0 \\
\hline & & & & & & & Sand & 130.0 & 148.0 \\
\hline & & & & & & & Dolomite & 148.0 & 340.0 \\
\hline & & & & & & & Sandstone & 340.0 & 415.0 \\
\hline \multirow[t]{6}{*}{24} & T027NR24WSEC30 & 205561 & 139 & 135 & NA & 4 & Clay & 0.0 & 10.0 \\
\hline & & & & & & & Sand & 10.0 & 70.0 \\
\hline & & & & & & & Clay & 70.0 & 123.0 \\
\hline & & & & & & & Gravel & 123.0 & 132.0 \\
\hline & & & & & & & Sand and gravel & 132.0 & 135.0 \\
\hline & & & & & & & Sand & 135.0 & 139.0 \\
\hline 25 & T115NR17W33CA & 653913 & 50 & 45 & 5 & NA & Soil & 0 & 4 \\
\hline $25 \mathrm{~A}$ & -- & 653915 & 85 & 80 & 5 & NA & Fine silty sand & 4 & 85 \\
\hline
\end{tabular}

of water-level rise and recession during those periods.

\section{AGE DATING OF SHALLOW GROUND WATER}

Age dating of shallow, unconfined ground water was done to estimate recharge based on concentrations of an environmental tracer in groundwater samples collected from two nested wells identified as 25 and $25 \mathrm{~A}$.
In this method, age-depth profiles determined from concentrations of the environmental tracer $\mathrm{SF}_{6}$, combined with the porosity of the aquifer in which the sampled wells are completed, were used to derive site-specific estimates of recharge. The estimates represent a mean annual rate during the period defined by the age of the ground water.
The age-depth profiles indicate the velocity of downward ground-water flow-calculated as the depth below the water table where the sample was collected divided by the age of the ground-water sample. Recharge was calculated based on the following relation of downward ground-water flow velocity and aquifer porosity:

$$
R=V \cdot \phi
$$

where $R$ is recharge (in./yr); 


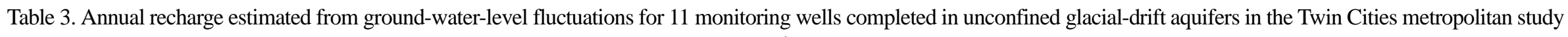
area, Minnesota

[all data reported in inches; --, indicates no data; --, not computed]

\begin{tabular}{|c|c|c|c|c|c|c|c|c|c|c|c|c|}
\hline \multirow{2}{*}{ Year } & \multicolumn{11}{|c|}{ Monitoring well identifiers (shown on figure 1) } & \multirow{2}{*}{$\begin{array}{c}\text { Median annual } \\
\text { value for the } 11 \text { wells }\end{array}$} \\
\hline & 1 & 2 & 3 & 4 & 5 & 6 & 7 & 8 & 9 & 10 & 11 & \\
\hline 1971 & -- & -- & 9.5 & 11.6 & -- & -- & -- & -- & -- & -- & -- & 10.6 \\
\hline 1972 & -- & -- & 9.9 & 6.9 & -- & -- & -- & -- & -- & -- & -- & 8.4 \\
\hline 1973 & -- & -- & 4.3 & 8.6 & -- & -- & -- & -- & -- & -- & -- & 6.4 \\
\hline 1974 & -- & -- & 4.8 & 11.9 & -- & -- & -- & -- & -- & -- & -- & 8.3 \\
\hline 1975 & -- & -- & 9.8 & 17.4 & -- & -- & -- & -- & -- & -- & -- & 13.6 \\
\hline 1976 & -- & -- & 3.5 & 7.2 & -- & -- & 8.7 & -- & -- & -- & -- & 7.2 \\
\hline 1977 & -- & -- & 5.0 & 16.3 & -- & -- & -- & -- & -- & -- & -- & 10.6 \\
\hline 1978 & 4.5 & -- & 7.0 & 16.0 & -- & -- & 4.9 & -- & -- & -- & -- & 5.9 \\
\hline 1979 & 16.2 & -- & 7.7 & 8.6 & -- & -- & 8.7 & -- & -- & -- & -- & 8.7 \\
\hline 1980 & 5.2 & -- & 4.0 & 10.8 & -- & -- & 3.6 & -- & -- & -- & -- & 4.6 \\
\hline 1981 & 7.8 & -- & 3.9 & 6.1 & 6.9 & -- & 2.9 & -- & -- & -- & -- & 6.1 \\
\hline 1982 & 9.1 & -- & 2.9 & 11.0 & 11.3 & -- & 15.6 & -- & -- & -- & -- & 11.0 \\
\hline 1983 & 6.8 & -- & 2.9 & 6.9 & 7.7 & -- & 17.8 & -- & -- & -- & -- & 6.9 \\
\hline 1984 & 9.1 & -- & 8.4 & 10.5 & 9.1 & -- & 4.5 & -- & -- & -- & -- & 9.1 \\
\hline 1985 & 6.5 & 3.3 & 4.6 & 12.4 & 12.7 & -- & -- & -- & -- & -- & 6.2 & 6.3 \\
\hline 1986 & 13.9 & 8.8 & 3.3 & 11.3 & 6.6 & -- & 12.6 & 12.0 & 31.8 & 12.0 & 17.2 & 12.0 \\
\hline 1987 & 6.8 & 3.6 & 4.6 & -- & 1.7 & -- & 4.5 & 4.5 & 7.5 & 5.2 & 1.9 & 4.5 \\
\hline 1988 & 3.6 & 5.0 & 3.3 & 4.4 & 10.2 & -- & 4.2 & 8.4 & 6.2 & 3.9 & 10.7 & 4.7 \\
\hline 1989 & 5.5 & 8.0 & 5.8 & 6.9 & 9.4 & -- & 3.2 & 5.5 & 3.9 & 3.2 & 6.5 & 5.7 \\
\hline 1990 & 11.7 & 9.9 & 5.2 & 12.4 & 13.2 & -- & 1.6 & 6.5 & 3.2 & 6.5 & 12.6 & 8.2 \\
\hline 1991 & 8.7 & 10.2 & 13.5 & 13.2 & 26.2 & -- & 18.5 & 3.6 & 12.0 & 18.8 & 22.4 & 13.4 \\
\hline 1992 & 6.5 & 10.8 & 3.6 & 4.4 & 4.7 & -- & 11.3 & 10.0 & 8.1 & 4.9 & 8.1 & 7.3 \\
\hline 1993 & 5.5 & 8.0 & 7.2 & 18.2 & 12.1 & 6.3 & 7.8 & -- & -- & 10.0 & 13.0 & 8.0 \\
\hline 1994 & -- & 24.6 & 15.5 & 21.5 & 5.0 & 4.7 & 4.9 & -- & 18.5 & 8.1 & 5.5 & 8.1 \\
\hline 1995 & -- & 8.3 & 9.5 & 15.7 & 10.2 & 9.4 & 14.6 & -- & 35.3 & 13.0 & 12.6 & 12.6 \\
\hline 1996 & 3.6 & 8.3 & 10.9 & 10.8 & 12.4 & 7.7 & 10.7 & -- & -- & 8.7 & 13.6 & 10.7 \\
\hline 1997 & 21.7 & -- & 10.6 & 10.5 & 8.0 & -- & 20.7 & -- & 23.0 & 8.1 & 10.0 & 10.6 \\
\hline 1998 & 19.1 & -- & 8.6 & 9.1 & 2.5 & 6.2 & 29.5 & -- & 14.3 & 14.9 & 7.1 & 9.1 \\
\hline 1999 & 7.5 & 11.0 & 4.8 & 7.5 & 2.8 & 6.1 & 6.2 & -- & 12.3 & 12.0 & 17.2 & 7.5 \\
\hline Mean $^{1}$ & 9.0 & 9.2 & 6.7 & 11.0 & 9.1 & 6.7 & 9.9 & 7.2 & 14.7 & 9.2 & 11.0 & $\mathrm{nc}$ \\
\hline Median $^{1}$ & 7.1 & 8.3 & 5.2 & 10.8 & 9.1 & 6.3 & 8.3 & 6.5 & 12.2 & 8.4 & 10.7 & $\mathrm{nc}$ \\
\hline Minimum $^{1}$ & 3.6 & 3.3 & 2.9 & 4.4 & 1.7 & 4.7 & 1.6 & 3.6 & 3.2 & 3.2 & 1.9 & $\mathrm{nc}$ \\
\hline Maximum $^{1}$ & 21.7 & 24.6 & 15.5 & 21.5 & 26.2 & 9.4 & 29.5 & 12.0 & 35.3 & 18.8 & 22.4 & $\mathrm{nc}$ \\
\hline
\end{tabular}

${ }^{1}$ For period of record 
$V$ is velocity (in./yr);

and $\phi$ is porosity (dimensionless).

Equation 1, which assumes a linear age-depth profile, simplifies the relation of recharge to downward groundwater flow velocity and aquifer porosity reported by Delin and others (2000), who assumed an exponential age-depth profile.

This method assumes that the recharge water is in equilibrium with the atmosphere in the unsaturated zone up to the time that the water reaches the water table, and that after that time the predominant movement of the recharge water is by piston flow downward at a constant velocity. This method furthermore assumes that fluctuations in the water table have been insignificant since the time of the recharge.

Anthropogenic chemical and isotopic substances released into the atmosphere during the past 50 years are used as environmental tracers. Some of these tracers, which include chlorofluorocarbons (CFCs), tritium $\left({ }^{3} \mathrm{H}\right)$, and $\mathrm{SF}_{6}$, have mixed and spread throughout the world, dissolved in precipitation, and entered into the hydrologic cycle. These tracers are now present in ground water, and their concentrations are indicators of the elapsed time (if less than 50 years) since recharge.

Significant production of $\mathrm{SF}_{6}$ began in the 1960's for use in electrical transformers. Other than electrical transformers, $\mathrm{SF}_{6}$ has few anthropogenic sources. This very stable substance has a long atmospheric lifetime that has been reported to range from 1,935 (Patra and others, 1997) to 3,200 years (Ravishankara and others, 1993). $\mathrm{SF}_{6}$ can be detected and analyzed in the atmosphere to a precision of 1-3 percent (Wanninkhof and others, 1991; Law and others, 1994). Given the low solubility of $\mathrm{SF}_{6}$ (Mroczek, 1997), apparent ages of ground-water samples can be very sensitive to the addition of excess air (air trapped in the aquifer during a rise in the water table) at the time of recharge, so an accurate measurement of the excess air concentration is very important. In this study the concentration of excess air was determined in ground-water samples collected from four wells (identified as 3A, 3B, 6, and 25A).

Despite small atmospheric mixing concentrations for $\mathrm{SF}_{6}$ - presently about 4 pptv (parts per trillion)—dating of ground water is for water recharged since about 1970. An analytical procedure has been developed for determination of $\mathrm{SF}_{6}$ concentrations in water to less than 0.01 femtomol per liter (fmol/L) (Busenberg and Plummer, 2000). As a result of this analytical procedure, ground water can be dated using $\mathrm{SF}_{6}$ within a range of 0-30 years if, at the time of recharge, the ground water was in equilibrium with atmospheric $\mathrm{SF}_{6}$ and was not contaminated with volatile organic compounds, such as methane, or significant amounts of $\mathrm{SF}_{6}$ from sources other than the atmosphere.

Atmospheric samples were collected from three sites in the study area and analyzed to verify that local atmospheric levels of $\mathrm{SF}_{6}$ were within the normal range observed for modern air throughout North America.

Results of these analyses indicated no locally significant sources of atmospheric $\mathrm{SF}_{6}$ that would preclude use of the method. At two well sites (identified as 3 and 6), where the method was attempted, methane contamination of local ground water invalidated the results of the $\mathrm{SF}_{6}$ analyses and precluded use of the method. Thus, recharge estimates were made only at site 25 .

\section{WATERSHED CHARACTERISTICS}

The watershed characteristics method, which is described in detail by Kudelin (1960) and Shmagin (1997), was used to make estimates of minimal ground-water recharge throughout the study area. In this report, the method is described in summary fashion. The method was used to estimate minimal recharge in three stages-first for the entire State of Minnesota, next for east-central Minnesota, and finally for the study area based on the results for east-central Minnesota.

The method results in estimates of minimal recharge to hydrogeologic units based on the unity of ground and surface waters (Winter and others, 1998) rather than for points or surface areas. Long-term streamflow records for the period 1935-81 were statistically analyzed in a multi-dimensional approach (Shmagin and others, 1998, 1999). Streamflow characteristics during this period of observation were considered representative of the entire state-wide streamflow data base.

The basis of the method is to acquire comparable minimal monthly base-flow data for watersheds, which entails analyses of streamflow data and associating these data with maps that depict the upperlying hydrogeologic units. The hydrogeologic units are depicted based on multiple-scale ground-water flow systems. The mapped units combined with the analyzed streamflow data become the basis for the estimation of minimal ground-water recharge by hydrogeologic regions and subregions.

The hydrogeologic region that includes the study area is the Paleozoic Artesian Basin, which extends throughout southeastern Minnesota (Shmagin and Kanivetsky, 2000). In the study area, two hydrogeologic subregions were identified-Quaternary sediments and Paleozoic confined bedrock aquifers. In these subregions, numerous areas and subareas were identified based on the stratigraphic sequence of Quaternary and Paleozoic bedrock units. The estimates of recharge estimated by this method were then mapped by these 
areal and subareal units. This method, therefore, is multi-scale in nature.

The principal quantitative watershed characteristic used in the method is minimal monthly streamflow.

Streamflow records indicate that monthly streamflow is lowest during February when streamflow typically consists of base flow (ground-water discharge) with little or no surface runoff. Minimal monthly streamflow data for east-central Minnesota (Lindskov, 1977) were compiled for 101 watersheds and analyzed by multivariate statistics (Shmagin and others, 1998, 1999). Based on these analyses, streamflow data for each analyzed watershed were adjusted in relation to the mean monthly streamflow for February during the common period of record (1935-81).

Based on analyses of the hydrogeologic and streamflow data, the February monthly streamflow was assumed to be a measure of the minimal ground-water recharge rate. This rate was considered a conservative estimate of actual recharge because the basis of estimation is February base flow. Recharge estimates by this method, therefore, are hereinafter termed minimal ground-water recharge. Although the statistical analyses used to assign values of minimal ground-water recharge are complex, the mapped values are easily understandable. These mapped values provide a useful representation of relative recharge rates in the study area.

\section{VERTICAL-HYDRAULIC GRADIENTS}

Leakage was estimated from analyses of vertical-hydraulic gradients for seven nested well sites (identified as 12-18, fig. 1, and table 2) based on application of the Darcy flow equation. These estimates are site specific and, therefore, representative of only localized areas surrounding each of the analyzed sites.
The Darcy flow equation has been used in many areas to quantify leakage through confining beds to confined aquifers. This equation is used where vertical-hydraulic gradients between aquifers can be determined from ground-water level data collected from nested wells. The hydraulic gradients, combined with the vertical-hydraulic conductivities of confining units through which the water flows, can be used to compute vertical interaquifer flow (leakage) according to the following form of the Darcy flow equation (Hantush, 1956)

$$
L=Q c / A c=
$$
$(\mathrm{k} / \mathrm{m}) \cdot \Delta h \cdot(12 \mathrm{in} / \mathrm{ft}) \cdot(365$ days $/ \mathrm{yr})$;

where $L$ is leakage (in./yr);

$Q c$ is the volumetric rate of leakage through the confining unit (ft $\left.{ }^{3} / \mathrm{yr}\right)$;

$A c$ is the area through which the leakage flows $\left(\mathrm{ft}^{2}\right)$;

$k$ is the vertical-hydraulic conductivity of the confining unit (ft/d);

$m$ is the thickness of the confining unit (ft);

$(\mathrm{k} / \mathrm{m})$ is the leakage coefficient, or leakance, of the confining unit, $\mathrm{d}^{-1}$; and

$\Delta h$ is the difference in hydraulic head between the aquifers separated by the confining unit ( $\mathrm{ft}$ ).

The hydraulic head difference between aquifers is the average difference of synoptic water levels in the nested wells during 1971-99. The water-level data associated with the wells at sites identified as $12,13,15$, 17 , and 18 were obtained from the Minnesota Department of Natural Resources monitoring well network data base (Minnesota Department of Natural Resources, 2000). The waterlevel data associated with the wells at sites identified as 14 and 16 were obtained from previously published reports (Reeder and others, 1976; Walton and others, 1991).

This study assumed a verticalhydraulic conductivity of $1.0 \times 10^{-6}$ $\mathrm{ft} / \mathrm{d}$ to calculate leakage flow through the glacial-drift and bedrock confining units. This value is based on estimates from previously published reports and written communications. vertical-hydraulic conductivity values reported for the following confining units-the Eau Claire, St.

Lawrence, and Franconia Formations-range from $2.1 \times 10^{-6}$ to $4.4 \times 10^{-}$

${ }^{3} \mathrm{ft} / \mathrm{d}$ (Walton and others, 1991).

Other estimated values for these confining units range from $2.1 \times 10^{-7}$ to $2.1 \times 10^{-4}$ (Runkel and Mossler, 2001).

Larson-Higdem and others (1975) estimated steady-state leakage to the Prairie du Chien-Jordan aquifer in about 75 percent of the study are based on application of the following variation of Darcy's law:

$$
(Q c / A c)=365 \cdot(K v / m) \cdot \Delta h
$$

where $Q c$ is leakage $\left(\mathrm{ft}^{3} / \mathrm{yr}\right)$;

$A c$ is area through which leakage occurs $\left(\mathrm{ft}^{2}\right)$;

$K v$ is vertical-hydraulic conductivity $(\mathrm{ft} / \mathrm{d})$;

$m$ is saturated thickness of deposits through which leakage occurs (ft); and

$\Delta h$ is the difference in hydraulic head between the Prairie du ChienJordan aquifer

and the overlying aquifer ( $\mathrm{ft}$ ).

A water-table map of the study area was constructed from water-levels in wells and from control points plotted on USGS 1:24,000 topographic maps where land-surface elevation contours crossed surface-water bodies. Additionally, a potentiometric surface map of the Prairie du ChienJordan aquifer was constructed from water-level data collected from wells completed in the aquifer. verticalhydraulic conductivities and saturated thicknesses of hydrogeologic units overlying the Prairie du ChienJordan aquifer were determined from previously published reports. After compilation of all data, equation 3 was coded into a computer program that calculated leakage rates $(Q c)$ for 
1-minute longitude by 1-minute latitude grid cells (about 600 acres).

Ideally, synoptic data would be used to construct a map of a watertable or potentiometric surface because of its dynamic nature. The time-scale controls in this study, however, spanned the survey dates on the USGS topographic maps, which were from 1916 to 1972 . Water-level data used to construct the water-table map were collected from 73 observation wells during November 27-28, 1973. The potentiometric surface of the Prairie du Chien-Jordan aquifer was defined from a synoptic measurement of water levels in wells during winter of 1970-71.

\section{ESTIMATES OF RECHARGE TO UNCONFINED AQUIFERS}

Recharge rates to unconfined aquifers were evaluated quantitatively based on analyses of: (1) precipitation; (2) streamflow-recession displacements; (3) ground-water level fluctuations; (4) age dating of shallow ground water; and (5) watershed characteristics. Recharge rates based on precipitation, streamflow-recession displacements, and watershed characteristics are areal estimates for broad areas, and recharge rates based on ground-water level fluctuations and age dating of shallow ground water are site-specific estimates for localized areas.

Figure 2 shows the study area in terms of the permeability of surficial materials, which is a qualitative indicator of recharge potential. In areas classified as greater than 75 percent impervious, recharge potential is expected to be smaller than in areas classified as surficial sand and gravel.

The impervious land areas correlate with the Minneapolis and St. Paul downtown areas and dispersed developments in surrounding suburbs. The surficial sand and gravel areas generally correlate with outwash deposits in Anoka, Dakota, and Washington Counties, and with both outwash and terrace deposits along the Minnesota River Valley in Carver and Scott Counties.

\section{PRECIPITATION}

Mean annual precipitation for the study area ranged from about 28 to 31 in./yr during the period 1961-90 and generally increased from west to east (fig. 3A). Annual recharge estimates based on these precipitation data also increased from west to east. Mean annual recharge, based on 27 percent of the mean annual precipitation, ranged from about 7.7 to $8.3 \mathrm{in} . / \mathrm{yr}$ (fig. 3B). Minimum and maximum annual recharge ranged from about 3.4 to $3.7 \mathrm{in.} / \mathrm{yr}$ (fig. 3C) and from about 12.4 to 13.6 in./yr (fig. 3D), based on 12 and 44 percent of the mean annual precipitation, respectively. Minimum (12 percent of precipitation) and maximum (44 percent of precipitation) recharge represent extreme rates expected under atypical hydrogeologic conditions that would be either less or more favorable for recharge.

These estimates of annual recharge are considered representative of portions of the study area that contain permeable, surficial sand and gravel, as shown in figure 2. Outside these portions of the study area, where the surficial materials are less permeable or impervious, recharge would be expected to be less. Recharge rates would not be expected to be uniform throughout the areal extent of the surficial sand and gravel, however, because of heterogeneities in these materials, topography, and land use.

\section{STREAMFLOW-RECESSION DISPLACEMENTS}

Annual recharge estimates based on the streamflow-recession displacement method for the seven analyzed basins ranged from $0.5 \mathrm{in} . / \mathrm{yr}$ (Elm Creek Basin-1988) to 13.5 in./yr. (Rum River Basin-1986) (table 1). The median and mean annual recharge rates estimated for these basins were 0.1 to $2.0 \mathrm{in./yr}$ smaller than the mean annual runoff (table 1). During each year of the period of record (1961-98), the median annual recharge was determined from available recharge estimates associated with each analyzed basin. These median values ranged from 1.2 to 12.2 in./yr (table 1; fig. 4). Although estimates of recharge for the basins represent single, integrated values, recharge in the basins would be expected to vary spatially because of variable hydrogeologic features and land-use patterns.

Recharge estimated by the streamflow-recession displacement method appeared to vary directly with precipitation (fig. 4). As a percentage of annual precipitation, the median recharge among the analyzed basins ranged from 11 to 21 percent (minimum and maximum of 5 and 34 percent, respectively) (table 1). The median recharge as a percentage of precipitation was smaller for Minnehaha Creek Basin (11 percent) than for the other analyzed basins (14-20 percent) because of a large proportion of impervious land area. Median recharge rates (as a percentage of precipitation) were relatively large in the Rum River and Vermillion River, and Nine Mile Creek Basins (17, 18, and 20 percent, respectively), because of extensive deposits of surficial sand and gravel (fig. 2). Slightly smaller median recharge rates for Purgatory Creek and Crow River Basins (14 percent each) are attributable to the presence of surficial deposits of lower permeability. A slightly smaller median recharge rate (18 percent of precipitation) was expected, but not observed, for Elm Creek Basin, where surficial sand and gravel deposits are sparse.

\section{GROUND-WATER LEVEL FLUCTUATIONS}

Annual recharge estimates ranged from 1.6 to $35.3 \mathrm{in./yr}$ based on the ground-water level fluctuation 


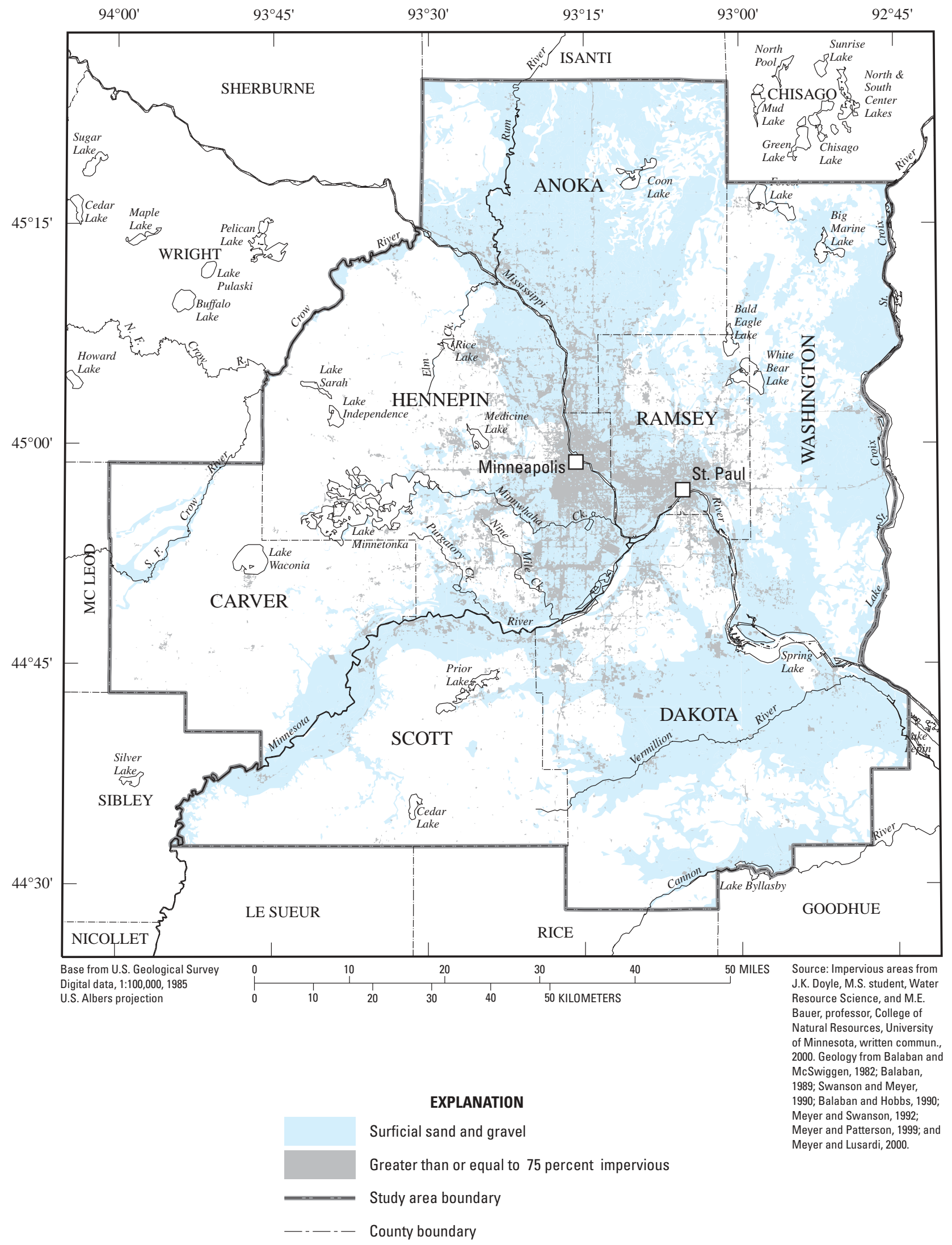

Figure 2. Areas of potential minimum and maximum recharge based on land-surface permeability in the Twin Cities metropolitan study area, Minnesota. 


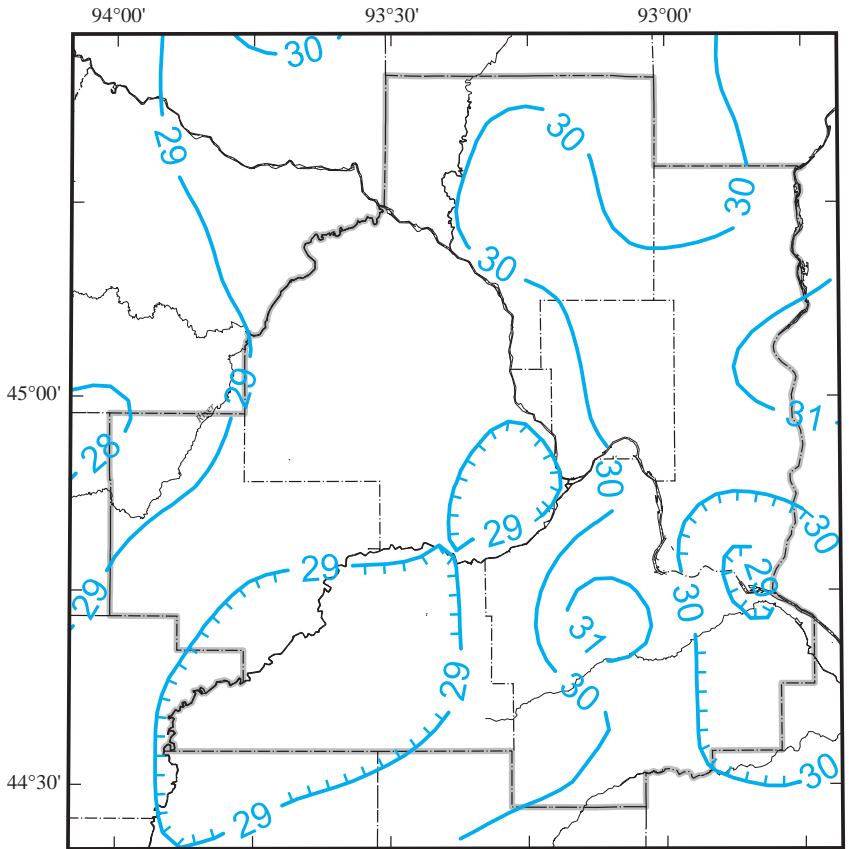

A. Mean annual precipitation, in inches (1961-90) (Contour interval is 1 inch)

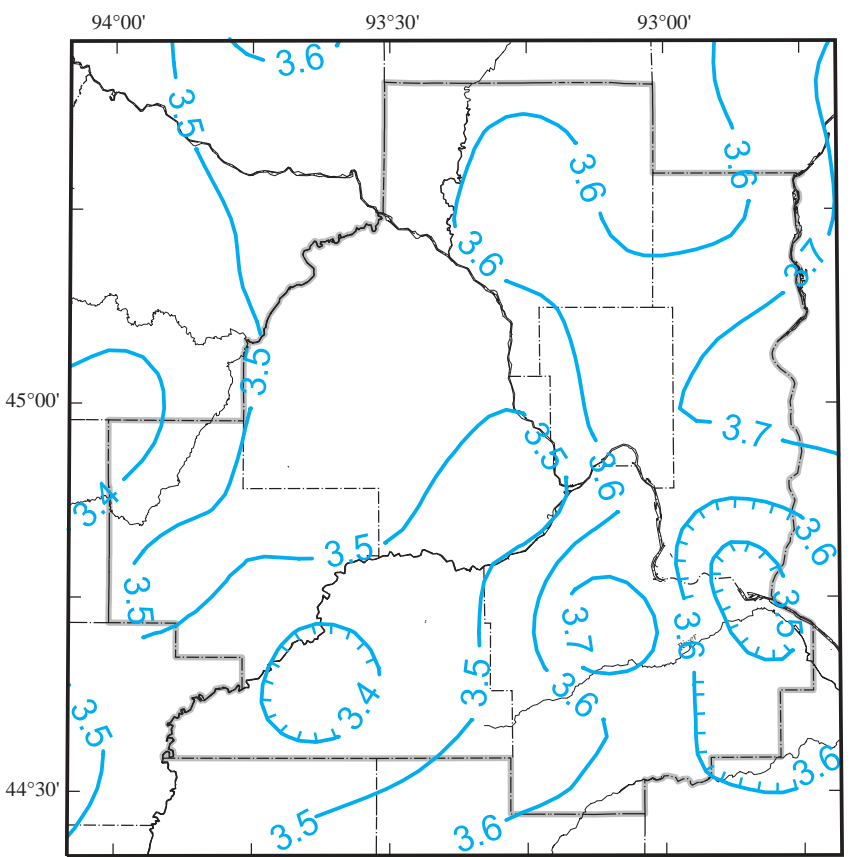

C. Minimum annual recharge, in inches, based on 12 percent of normal annual precipitation (Contour interval is 0.1 inch)

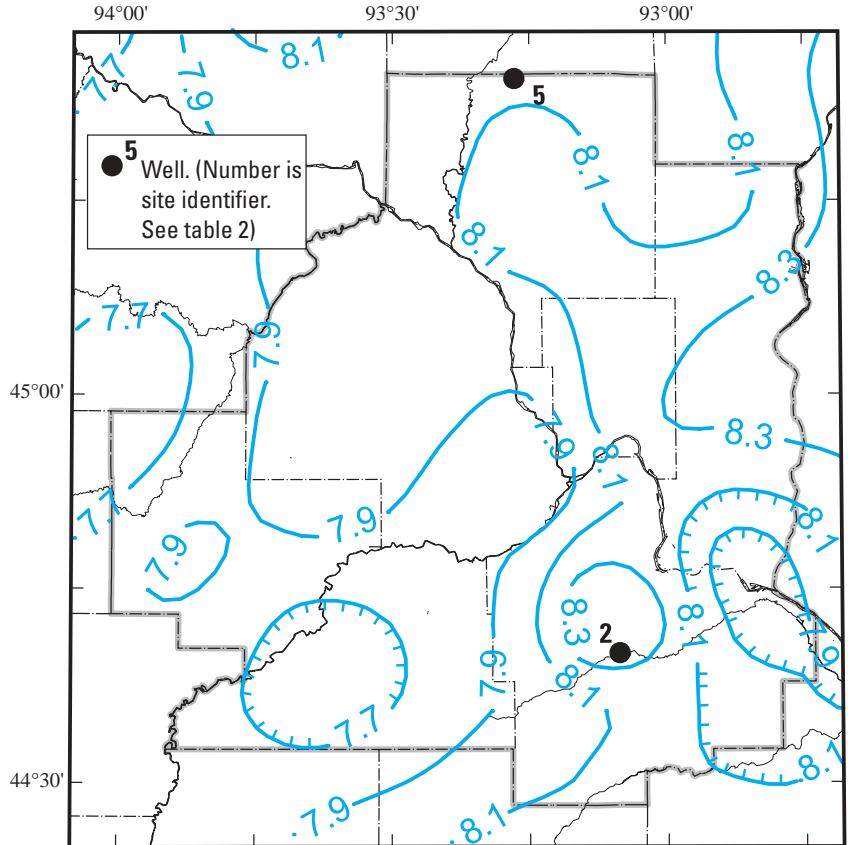

B. Mean annual recharge, in inches, based on 27 percent of normal annual precipitation (Contour interval is 0.2 inch)

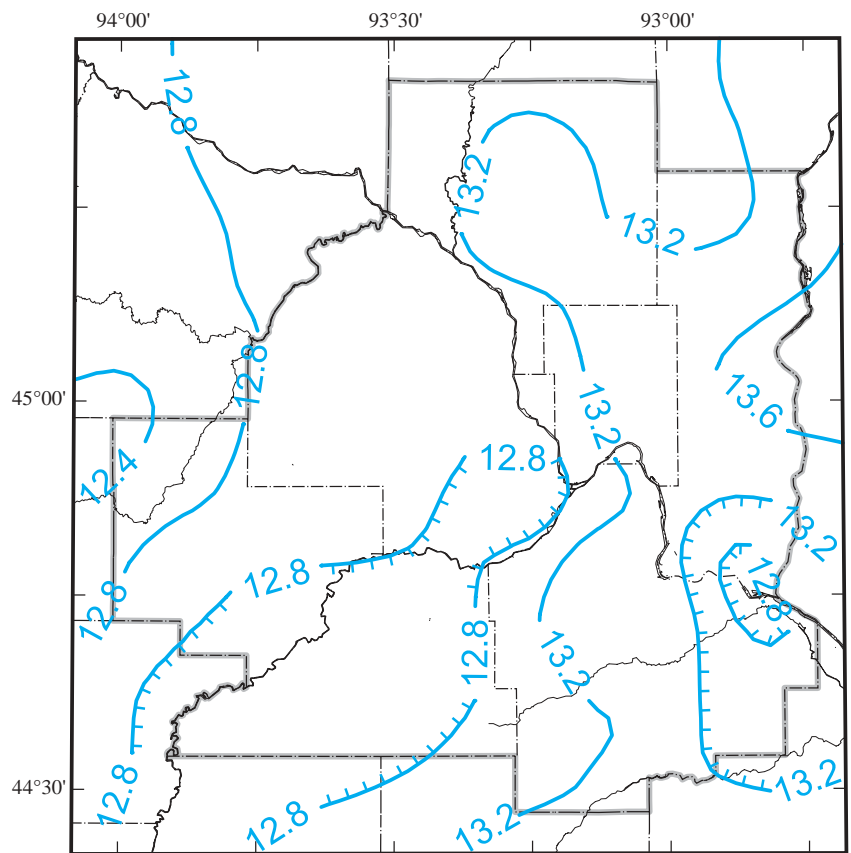

D. Maximum annual recharge, in inches, based on 44 percent of normal annual precipitation (Contour interval is 0.4 inch)

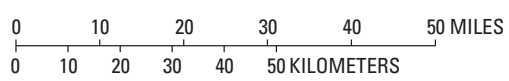

Figure 3. Recharge based on precipitation in the Twin Cities metropolitan study area, Minnesota. 

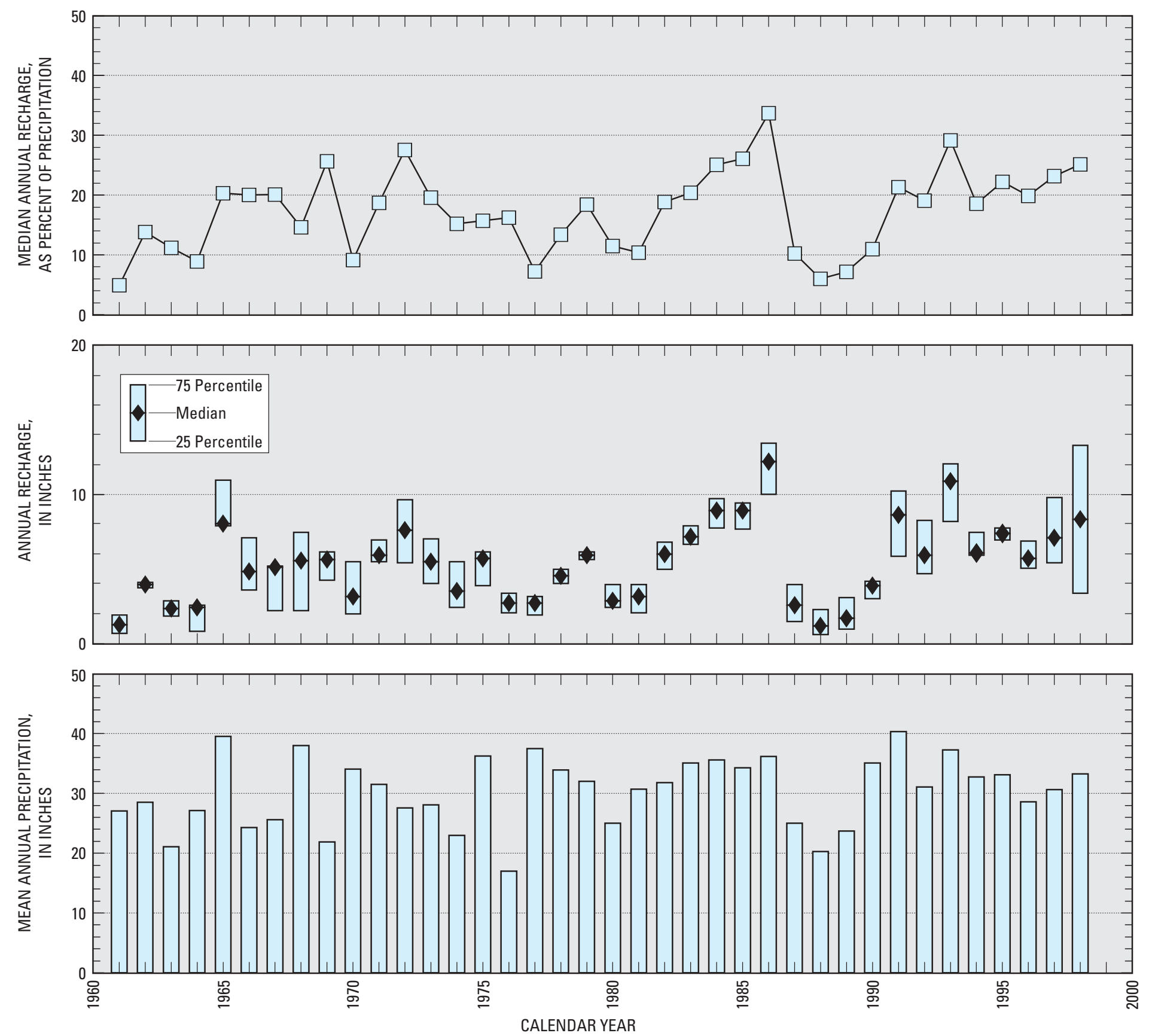

Figure 4. Median annual recharge based on streamflow-recession displacements for seven basins in the Twin Cities metropolitan study area, Minnesota.

method for the 11 analyzed wells screened in unconfined glacial-drift aquifers (table 3 ). Recharge estimates in the upper part of the range (estimates that exceed 20 in./yr) are unreasonably large. During each year of the period of record (1971-99), the median annual recharge was determined from available recharge estimates associated with each of the analyzed wells. These median values ranged from 4.5 to $13.6 \mathrm{in./yr}$ (table 3; fig. 5). These recharge estimates are representative of surficial sand and gravel (fig. 2).

Recharge estimated by this method appeared to vary directly with precipitation (fig. 5). As a percentage of annual precipitation, the median recharge among the analyzed wells ranged from about 18 to 42 percent. These values were consistent with the proportionality factors $(0.12,0.27$, and 0.44 ) based on Delin and others (2000).

\section{AGE DATING OF SHALLOW GROUND WATER}

The annual recharge estimate based on the age dating of shallow 

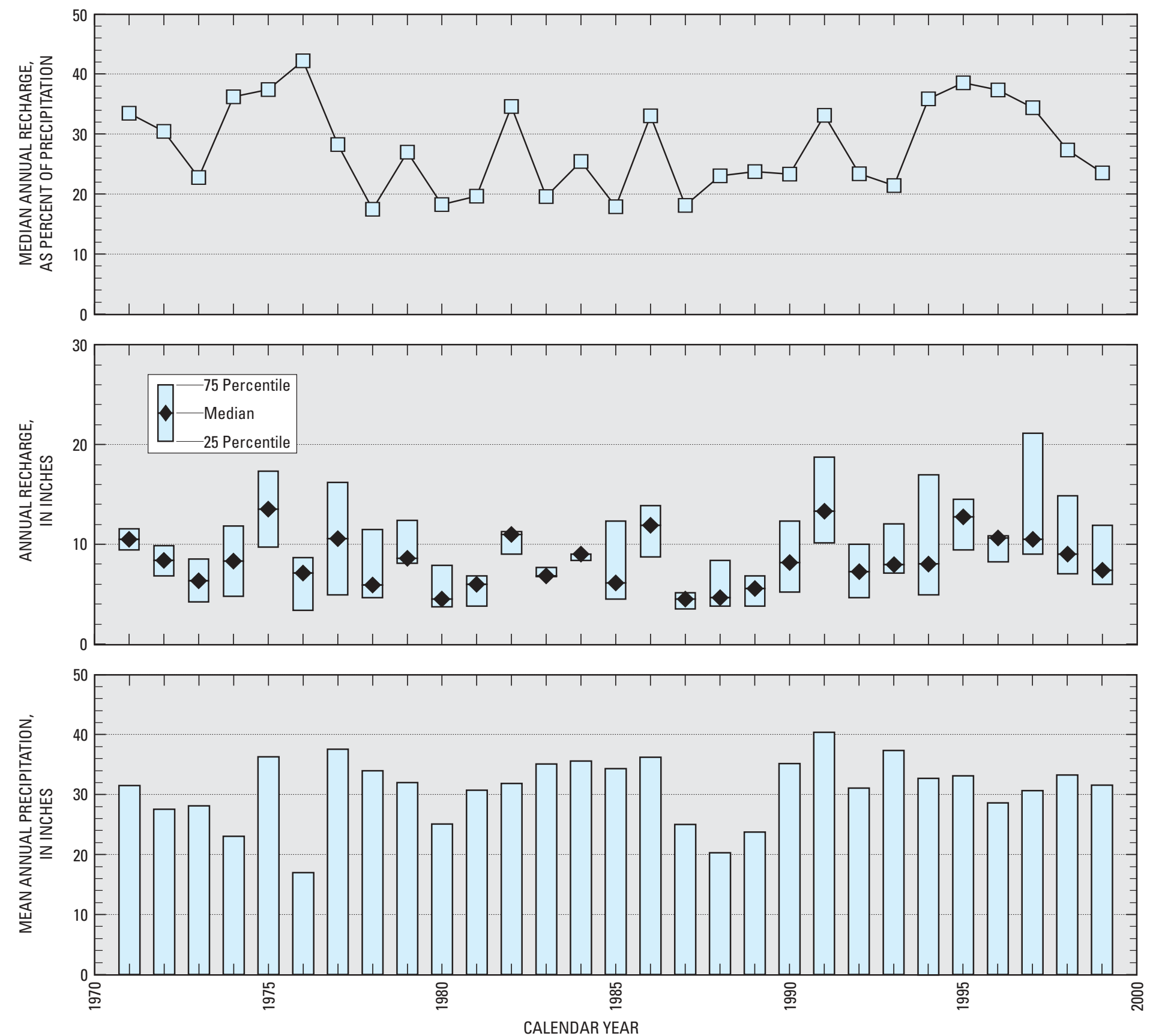

Figure 5. Median annual recharge based on ground-water level fluctuations for 11 wells in the Twin Cities metropolitan study area, Minnesota.

ground water method for one nested well site (identified as 25 ; fig. 1 ) was 8.8 in./yr. The concentrations of $\mathrm{SF}_{6}$ in ground-water samples from the wells at this site were $8.7 \mathrm{pptv}$ for the shallow well (identified as 25) and 6.2 pptv for the deep well (identified as 25A). These concentrations indicated an unknown, non-atmospheric source of $\mathrm{SF}_{6}$. Concentrations of $\mathrm{SF}_{6}$ in ground water that exceed 5.0 pptv are considered to contain more of this compound than could be accounted for by equilibration of the recharge water with atmospheric $\mathrm{SF}_{6}$.

The non-atmospheric source of $\mathrm{SF}_{6}$ most likely was anthropogenic (caused by the disposal of waste products that released $\mathrm{SF}_{6}$ into the ground water). Another source of $\mathrm{SF}_{6}$ could be natural, such as a mineral. If the amounts of non-atmospheric $\mathrm{SF}_{6}$ in ground-water samples from the two wells are assumed equivalent, the difference in age in water from these wells was about 19 years-water from the deeper well being older than water from the shallower well (Ed Busenberg, Hydrologist, U.S. Geological Survey, written commun., 2001). 
Calculation of the recharge rate from equation 1 was based on a difference in screen depths between the two wells of $35 \mathrm{ft}$ and an assumed porosity of 0.40 (McWhorter and Sunada, 1977) for the aquifer in which the wells were completed. The calculated annual recharge rate of $8.8 \mathrm{in./yr}$ compares closely to that estimated by the Darcy flow equation method for this well site, which was about $8.1 \mathrm{in} . / \mathrm{yr}$. Application of the Darcy flow equation assumed a vertical-hydraulic conductivity of $0.01 \mathrm{ft} / \mathrm{d}$, a value that would typify a sand and gravel aquifer (Freeze and Cherry, 1979).

\section{WATERSHED CHARACTERISTICS}

Minimal ground-water recharge in the study area, as determined by the watershed characteristics method, generally ranged from 0.1 to less than 2.5 in./yr. Figure 6 shows the variation of minimal ground-water recharge for five ranges-from less than 0.1 to greater than $2.5 \mathrm{in} . / \mathrm{yr}$. Each of the three ranges that represent recharge from 0.1 to less than 2.5 in./yr extend over a similarly sized portion of the study area. The range mapped with the largest area (1.5 to less than $2.5 \mathrm{in} . / \mathrm{yr}$ ) generally correlates with the surficial sand and gravel deposits shown on figure 2 . These results are expected based on the relation of surficial permeability to potential recharge discussed earlier. In the southeastern part of the study area minimal ground-water recharge was greater than or equal to $2.5 \mathrm{in}$./yr (fig. 6 ), with a maximum of $5.6 \mathrm{in} . / \mathrm{yr}$. In a still smaller portion of the southeastern part of the study area, the rate was less than $0.1 \mathrm{in./yr}$. This area correlates with subcrops of the Platteville Limestone and Glenwood Shale (Mossler and Tipping, 2000), which are Ordovician bedrock formations that collectively act as a confining unit.

\section{ESTIMATES OF LEAKAGE TO CONFINED AQUIFERS}

Recharge to confined glacial-drift and bedrock aquifers is by leakage through overlying confining units. Annual rates of leakage to these aquifers are much smaller than annual rates of recharge to unconfined aquifers. Subcrop areas of confined bedrock aquifers where the overlying material is glacial drift are potentially important source areas of recharge to the aquifers, particularly where the overlying drift is thin and permeable (fig. 7).

Leakage rates estimated by analyses of ground-water level fluctuations and vertical-hydraulic gradients were less than $1 \mathrm{in./yr}$ (figs. 8-9). These rates are site-specific to localized areas around the analyzed wells. These estimates, therefore, would not be expected to be transferable to portions of the study area with hydrogeologic settings dissimilar to that near the analyzed wells. Area-wide estimates of leakage rates to the Prairie du Chien-Jordan aquifer also were evaluated based on results of a study by Larson-Higdem and others (1975) that analyzed vertical-hydraulic gradients over a broad region of the study area.

\section{GROUND-WATER LEVEL FLUCTUATIONS}

Leakage to confined aquifers estimated by the ground-water level fluctuation method for 11 wells ranged from $3.2 \times 10^{-3}$ to $1.1 \times 10^{-2}$ in./yr (fig. 8 ). These rates did not vary with hydrogeologic unit. Most of the wells were completed in bedrock units-7 wells (identified as 17-23) were completed in the Prairie du Chien-Jordan aquifer and 1 well (identified as well 15B) was completed in the IrontonGalesville aquifer. Three other wells (identified as 15, 15A, and 24) were completed in confined glacial-drift aquifers. All of the bedrock wells are located in or at the edge of the aquifer subcrop areas where leakage to these areas would be affected by the thickness and permeability of the overlying drift.

\section{VERTICAL-HYDRAULIC GRADIENTS}

Leakage estimated by analyses of vertical-hydraulic gradients based on the Darcy flow equation for seven nested well sites ranged from $4.6 \times 10^{-5}$ to $1.1 \times 10^{-1}$ in./yr (fig. 9). The smallest leakage rate was estimated for the Ironton-Galesville aquifer, and the next smallest rate $\left(5.3 \times 10^{-5} \mathrm{in} . / \mathrm{yr}\right)$ was estimated for a confined glacialdrift aquifer. The two largest rates $\left(6.4 \times 10^{-2}\right.$ and $\left.1.1 \times 10^{-1} \mathrm{in} . / \mathrm{yr}\right)$ were estimated for the Prairie du Chien-Jordan aquifer. The other rates, which varied within an order of magnitude $\left(2.1 \times 10^{-4}\right.$ to $\left.9.3 \times 10^{-3} \mathrm{in.} / \mathrm{yr}\right)$, were estimated for the St. Peter, IrontonGalesville, and Mt. Simon-Hinckley aquifers.

\section{AREAL LEAKAGE TO THE PRAIRIE DU CHIEN-JORDAN AQUIFER}

Figure 10 shows areal leakage rates to the Prairie du Chien-Jordan aquifer based on application of the Darcy flow equation to verticalhydraulic gradients (Larson-Higdem and others, 1975). The rates, which were estimated for areal units of about 600 acres in size in about 75 percent of the study area, are considered small-scale estimates. The rates are mapped in terms of the following ranges: 0 to less than 4 in./yr; 4 to less than 8 in./yr; 8 to less than 12 in./yr; and greater than or equal to $12 \mathrm{in./yr}$ The lowest of these ranges, which is the most prevalent, generally extends throughout areas where the Prairie du Chien-Jordan aquifer is overlain by the basal St. Peter confining unit and thick glacial drift. The higher ranges of leakage rates were estimated in subcrop areas of the Prairie du ChienJordan aquifer where the overlying 


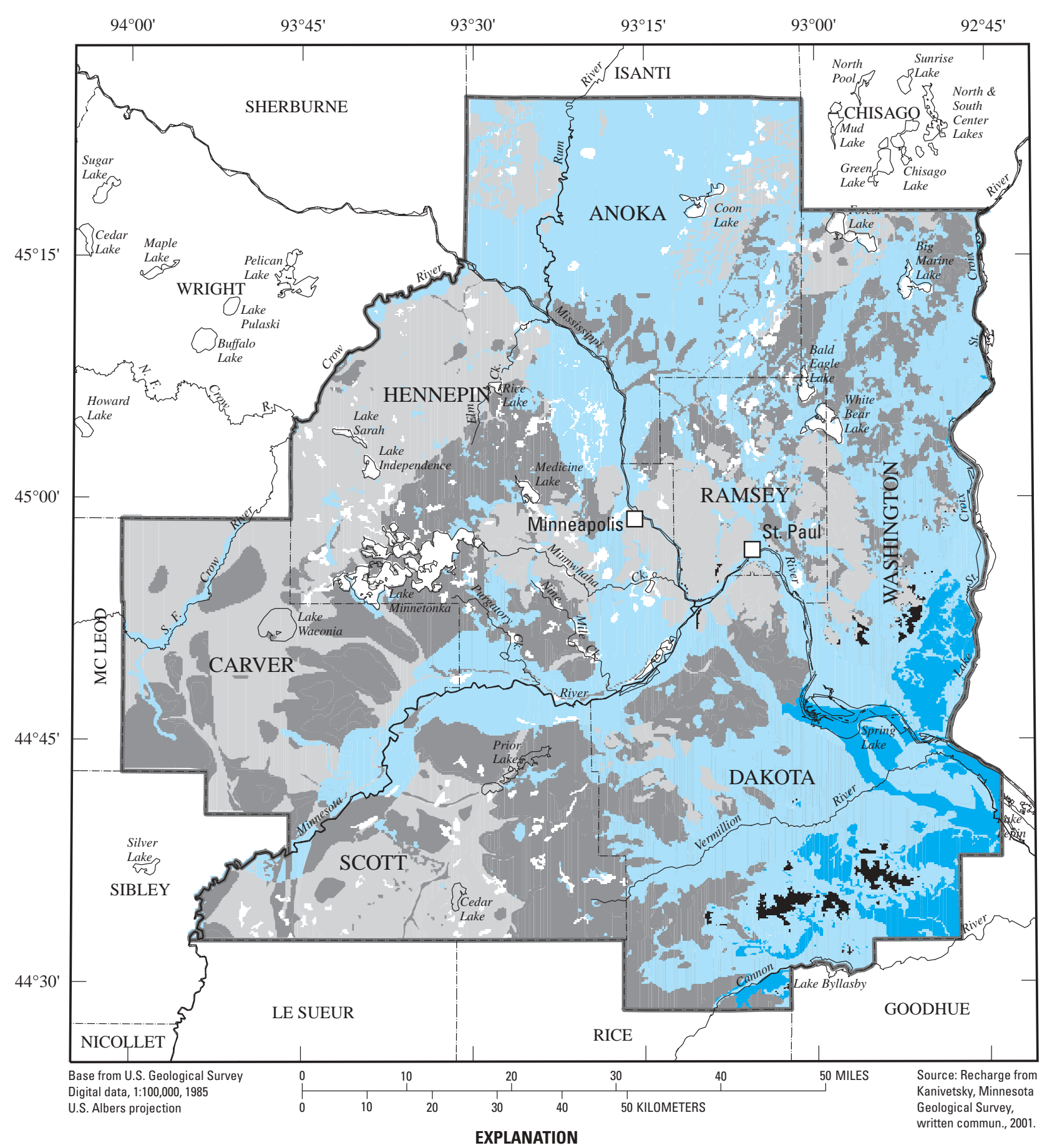

Minimal recharge ranges,

in inches per year

\begin{tabular}{l} 
Greater than or equal to 2.5 \\
1.5 to less than 2.5 \\
0.5 to less than 1.5 \\
0.1 to less than 0.5 \\
less than 0.1 \\
\hline Study area boundary \\
\hline - County boundary
\end{tabular}

Figure 6. Minimal ground-water recharge based on statistical analyses of watershed characteristics in the Twin Cities metropolitan study area, Minnesota. 


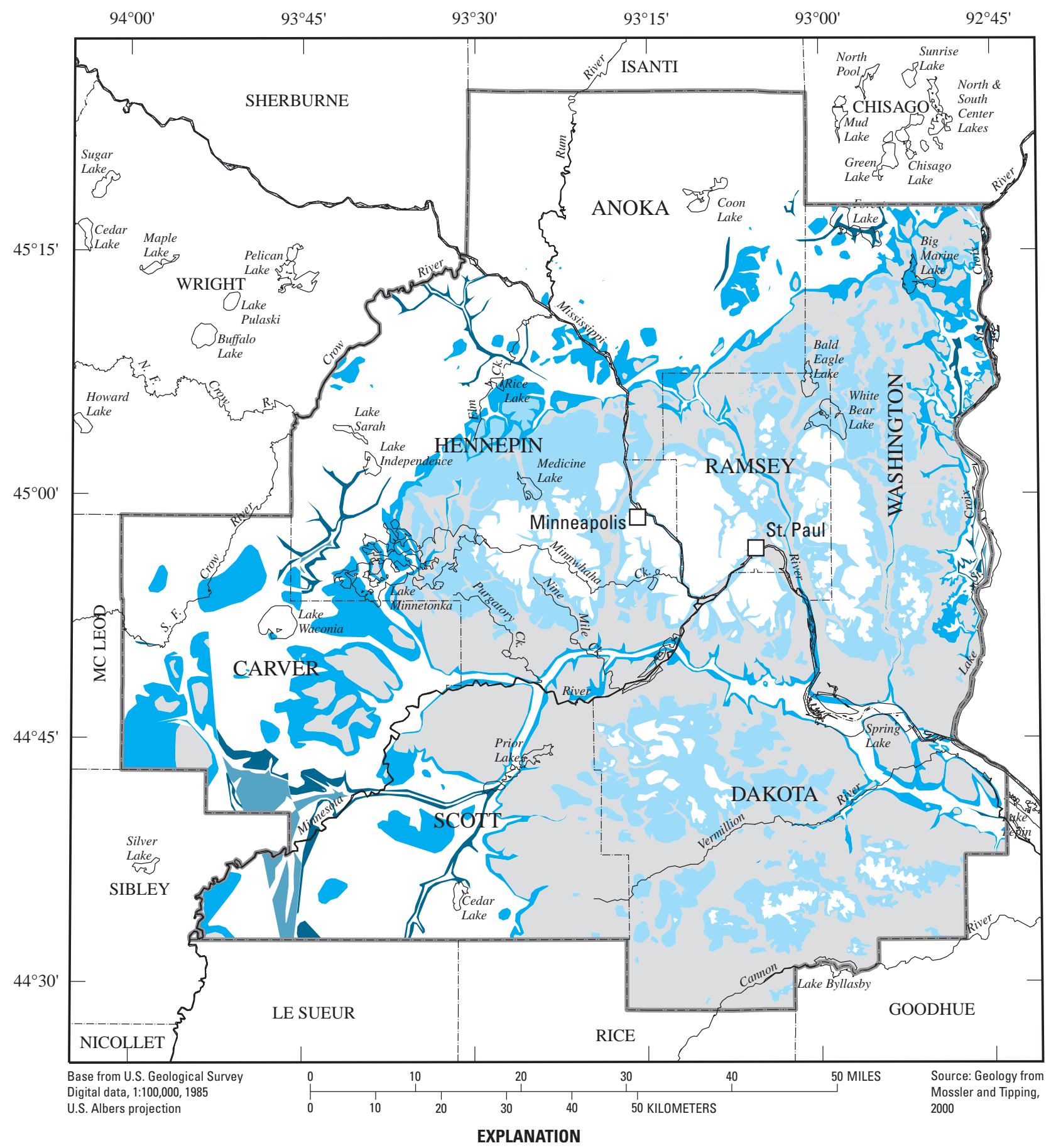

Principal bedrock formations

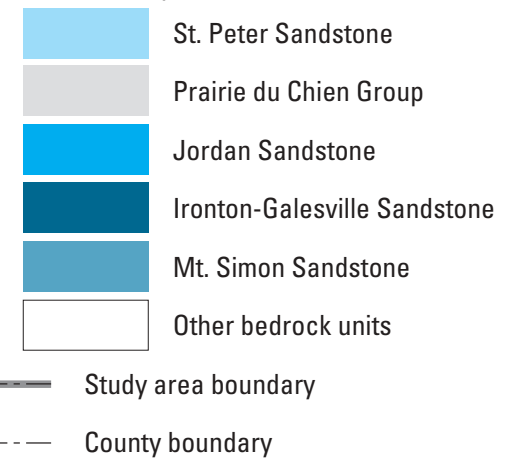

Figure 7. Subcrops of principal bedrock formations that contain aquifers in the Twin Cities metropolitan study area, Minnesota. 


\begin{tabular}{|c|c|c|c|c|c|c|c|c|c|c|c|c|}
\hline & & \multicolumn{11}{|c|}{ WELLS LISTED BY SITE AND WELL IDENTIFIER AND PERIODS OF WATER-LEVEL RECORD } \\
\hline & $\begin{array}{r}\text { SITE IDENTIFIER } \\
\text { WELL IDENTIFIER } \\
\text { PERIOD OF RECORD } \\
\end{array}$ & $\begin{array}{c}15 \\
15 \\
1980-99 \\
\end{array}$ & $\begin{array}{r}15 \\
150 \\
1980-99 \\
\end{array}$ & $\begin{array}{c}15 \\
15 B \\
1980-99 \\
\end{array}$ & $\begin{array}{c}17 \\
17 \\
1976-99\end{array}$ & $\begin{array}{c}18 \\
18 \\
1979-93 \\
\end{array}$ & $\begin{array}{c}19 \\
19 \\
1984-99 \\
\end{array}$ & $\begin{array}{c}20 \\
20 \\
1984-99 \\
\end{array}$ & $\begin{array}{c}21 \\
21 \\
1984-99 \\
\end{array}$ & $\begin{array}{c}22 \\
22 \\
1996-99 \\
\end{array}$ & $\begin{array}{c}23 \\
23 \\
1971-92 \\
\end{array}$ & $\begin{array}{c}24 \\
24 \\
1979-99 \\
\end{array}$ \\
\hline \multirow{14}{*}{ 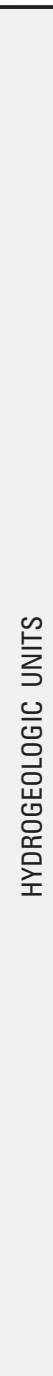 } & GLACIAL-DRIFT AQUIFERS & & & & & & & & & & & \\
\hline & \multicolumn{12}{|l|}{ GLACIAL-DRIFT CONFINING UNITS } \\
\hline & $\begin{array}{l}\text { CONFINED GLACIAL-DRIFT } \\
\text { AQUIFERS } \\
\text { Storage coefficient }=1.0 \times 10^{-4}\end{array}$ & $7.4 \times 10^{-3}$ & $4.7 \times 10^{-3}$ & & & & & & & & & $3.2 \times 10^{-3}$ \\
\hline & DECORAH CONFINING UNIT & & & & & & & & & & & \\
\hline & PLATTEVILLE CONFINING UNIT & & & & & & & & & & & \\
\hline & GLENWOOD CONFINING UNIT & & & & & & & & & & & \\
\hline & ST. PETER AQUIFER & & & & & & & & & & & \\
\hline & BASAL ST. PETER CONFINING UNIT & & & & & & & & & & & \\
\hline & $\begin{array}{l}\text { PRAIRIE DU CHIEN-JORDAN } \\
\text { AQUIFER } \\
\text { Storage coefficient }=1.0 \times 10^{-4}\end{array}$ & & & & $1.0 \times 10^{-2}$ & $5.3 \times 10^{-3}$ & $7.3 \times 10^{-3}$ & $4.4 \times 10^{-3}$ & $9.1 \times 10^{-3}$ & $1.1 \times 10^{-2}$ & $4.9 \times 10^{-3}$ & \\
\hline & ST. LAWRENCE CONFINING UNIT & & & & & & & & & & & \\
\hline & \multicolumn{12}{|l|}{ FRANCONIA CONFINING UNIT } \\
\hline & $\begin{array}{l}\text { IRONTON-GALESVILLE AQUIFER } \\
\text { Storage coefficient }=1.0 \times 10^{-4}\end{array}$ & & & $8.0 \times 10^{-3}$ & & & & & & & & \\
\hline & EAU CLAIRE CONFINING UNIT & & & & & & & & & & & \\
\hline & MT. SIMON-HINCKLEY AQUIFER & & & & & & & & & & & \\
\hline
\end{tabular}

Well locations shown on figure 1.

\section{EXPLANATION}

$3.2 \times 10^{-3}$ Leakage to aquifer, in inches per year

No data

Figure 8. Leakage based on ground-water level fluctuations for 11 wells in the Twin Cities metropolitan study area, Minnesota.

glacial drift is thin and permeable.

Many of the subcrop areas were near the major rivers (Mississippi, Minnesota, and St. Croix), where estimated leakage rates generally were in the range of 8 to less than $12 \mathrm{in./yr}$ or greater than $12 \mathrm{in./yr}$.
In the study by Larson-Higdem and others (1975), the verticalhydraulic conductivities of confining units overlying the Prairie du ChienJordan aquifer were adjusted where necessary so that the mean leakage rate was equal to $5.24 \mathrm{in./yr}$, the esti- mated basin-storage discharge of the study area (Norvitch and others, 1973). This adjustment was made because the Prairie du Chien-Jordan aquifer was considered the predominant source of basin-storage discharge, and leakage to the Prairie du 


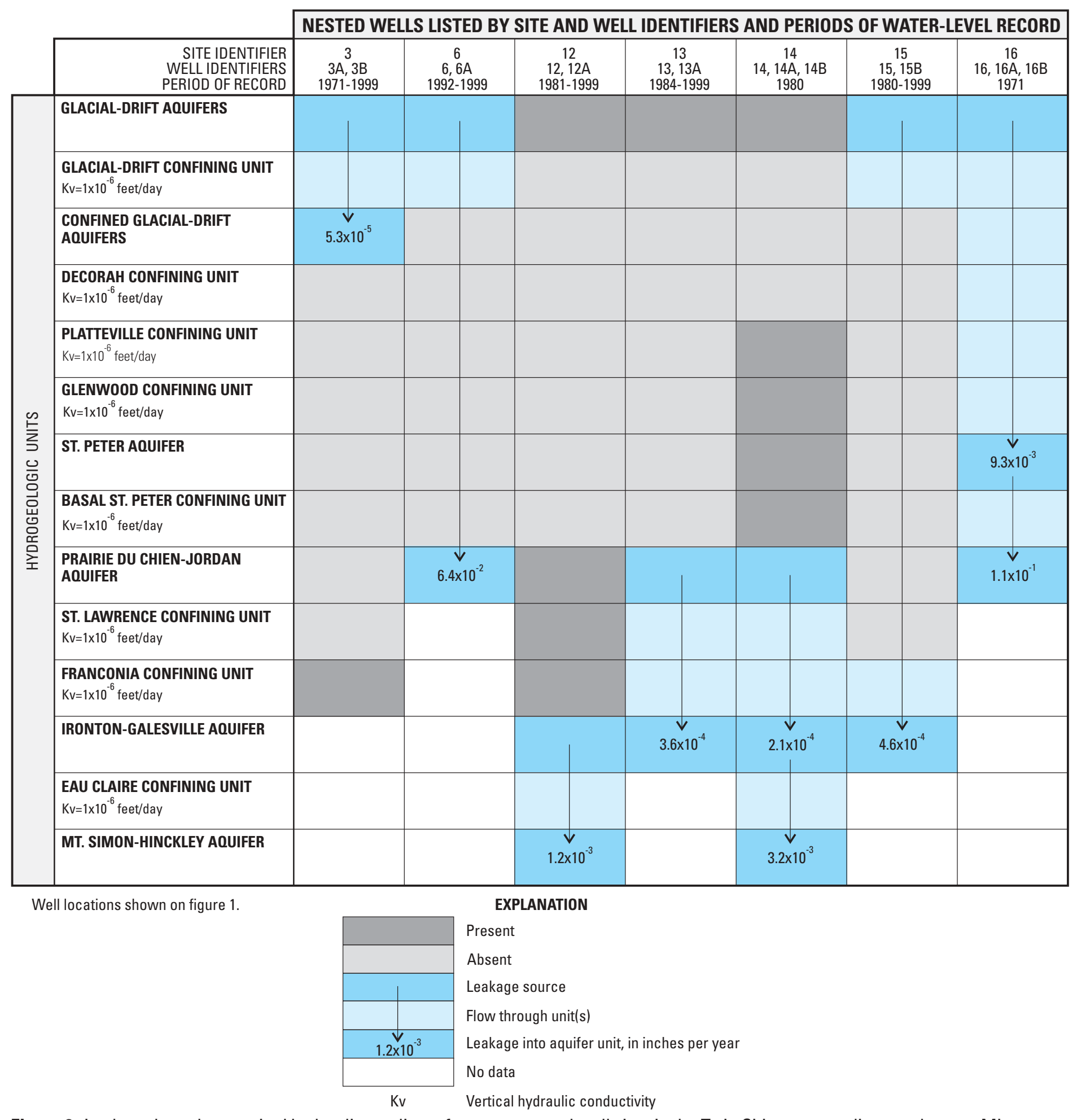

Figure 9. Leakage based on vertical hydraulic gradients for seven nested well sites in the Twin Cities metropolitan study area, Minnesota.

Chien-Jordan aquifer was considered approximately equivalent to this discharge. Although accurate determination of total leakage to the Prairie du Chien-Jordan aquifer was not determined, an approximate distribution of unit leakage was mapped throughout most of the study area. Absolute values of estimated leakage rates, therefore, were not considered as important as comparative rates in the study by Higdem-Larson and others (1975).
COMPARISON OF METHODS

Estimated rates of recharge and leakage estimated by the different methods were compared to each other in terms of their variability and relative magnitudes (table 4). These com- 


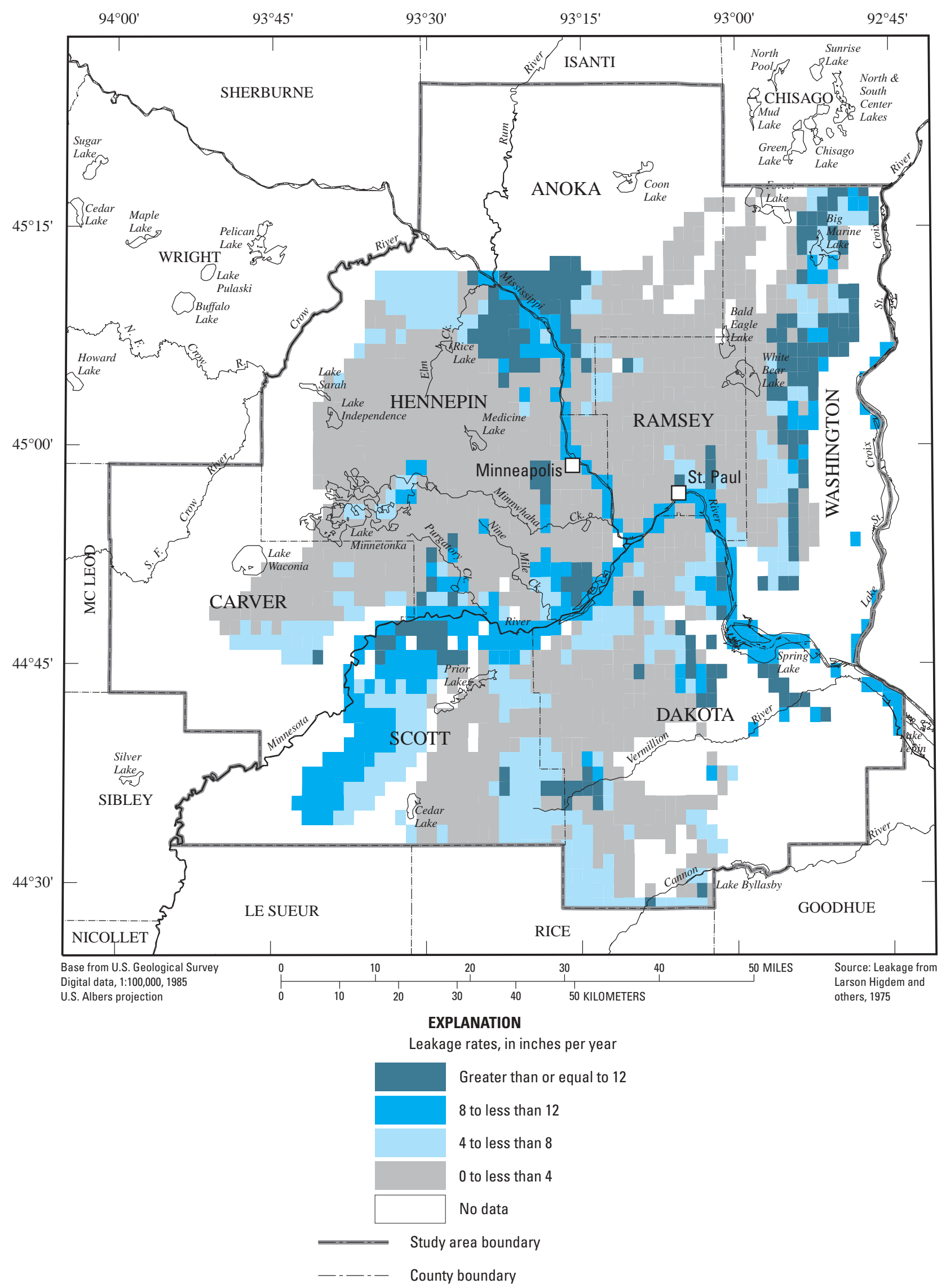

Figure 10. Leakage to the Prairie du Chien-Jordan aquifer based on vertical hydraulic gradient method in the Twin Cities metropolitan study area, Minnesota. 
parisons were made based on results estimated for the entire study area. Additionally, these comparisons were made for selected sites where the results from more than one method could be directly compared on a sitespecific basis.

\section{METHODS TO ESTIMATE RECHARGE}

The recharge estimates for each of the methods generally varied less than 10 in./yr. Estimates were largest for the ground-water level fluctuation (4.5-13.6 in./yr) and precipitation methods (7.7-8.3 in./yr), slightly greater for the age dating of shallow ground water ( $8.8 \mathrm{in./yr}$ ) and streamflow-recession displacement methods (1.2-12.2 in./yr), and smallest for the watershed characteristics method (< $0.1-5.6$ in./yr).

The results of the ground-water level fluctuation and age dating of shallow ground-water methods are site specific to the analyzed wells. The locations of these wells are in areas of surficial sand and gravel where recharge is expected to be greatest. Results of these methods are expected to reflect maximum or near maximum potential rates of recharge. Results of the streamflow-recession displacement method, which represents mean rates of recharge for basins, are determined by the entire range of recharge conditions in the basins. Results of this method would be somewhat smaller than that for the ground-water level fluctuation method.

Mean annual recharge based on precipitation analyses was slightly greater than the age dating of shallow ground-water method and within the range of the ground-water level fluctuation and streamflow-recession displacement methods. These results indicate the proportionality factor of 0.27 used to estimate mean annual recharge from mean annual precipitation was reasonable. Compared to the ground-water level fluctuation and streamflow-recession displacement methods, the variation in recharge for the precipitation method was small because of its linear relation to precipitation, which varied little across the study area. The recharge estimates based on the watershed characteristics method are conservative because they are based on February low-flow streamflow data.

Comparison of estimated recharge by the different methods were made for well 2 in the Vermillion River Basin, and well 5 in the Rum River Basin (table 4). The estimates of recharge associated with these wells by the ground-water level fluctuation method and with their respective basins by the streamflow-recession displacement method have common periods of record of several years or more. The comparison of results for the two wells and basins are presented in the following sections.

\section{Vermillion River Basin and Well 2}

Recharge rates for well 2 based on the ground-water level fluctuation method and for the Vermillion River Basin based on the streamflow-recession displacement method have a common period of record during 1985-96. During this period, recharge estimates for well 2 ranged from 3.3 in./yr to an anomalously high value of $24.6 \mathrm{in} . / \mathrm{yr}$, and had a median value of 8.3 in./yr (tables 3 and 4). During the same period, recharge estimates for the Vermillion River Basin ranged from 2.9 to $13.1 \mathrm{in} . / \mathrm{yr}$, and had a median value of 7.1 in./yr. Disregarding the anomalously high estimate, the absolute difference in annual recharge between the ground-water level fluctuation and streamflowrecession displacement methods ranged from 0.5 to $5.8 \mathrm{in} . / \mathrm{yr}$ (median of $2.7 \mathrm{in./yr}$ ). Mean annual recharge based on the precipitation method for the area surrounding well 2 was approximately $8.3 \mathrm{in./yr}$ (fig. 3). The time scale (1961-90) for this estimate (based on precipitation), however, dif- fered from the two previously discussed estimates.

Recharge rates based on the ground-water level fluctuation, streamflow-recession displacement, and precipitation analyses methods in the Vermillion River Basin generally were consistent with each other. Recharge rates based on the watershed characteristics method ranged from 1.5 to less than $2.5 \mathrm{in}$./yr. This range, although considerably smaller than the other methods, is relatively large for this method.

\section{Rum River Basin and Well 5}

Recharge rates estimated for well 5 by the ground-water level fluctuation method and for the Rum River Basin by the streamflow-recession displacement method have a common period of record during 1981-98. During this period, recharge estimates for well 5 ranged from 1.7 to an anomalously high value of $26.2 \mathrm{in./yr}$, and had a median value of $9.2 \mathrm{in} . / \mathrm{yr}$ (table 3). During the same period, recharge estimates for the Rum River Basin ranged from 1.8 to $13.5 \mathrm{in}$./yr and had a median value of 5.5 in./yr. Disregarding the anomalously high estimate, the absolute difference in annual recharge between the groundwater level fluctuation and streamflow-recession displacement methods ranged from 0.7 to $9.0 \mathrm{in}$./yr (median of 3.3 in./yr). Mean annual recharge estimated by the precipitation method for the area surrounding well 5 was approximately $8.0 \mathrm{in./yr}$ (fig. 3). The time scale (1961-90) for this estimate (based on precipitation), however, differed from the two previously discussed estimates.

At well site 5, the median recharge estimated by the ground-water level fluctuation method and the mean recharge estimated by the precipitation method were similar to each other. These estimates of recharge, however, were about twice as large as the median recharge estimated by the streamflow-recession displacement 
Table 4.--Comparison of recharge and leakage estimates based on multiple methods in the Twin Cities metropolitan area, Minnesota . (All values reported in units in inches per year; <, less than; >, greater than; NA, not applicable; --, no data; nd, not determined)

\begin{tabular}{|c|c|c|c|c|c|c|c|c|c|c|c|c|}
\hline \multirow[b]{2}{*}{$\begin{array}{l}\text { Well site } \\
\text { number }{ }^{1}\end{array}$} & \multirow[b]{2}{*}{$\begin{array}{c}\text { Well } \\
\text { identifier }^{2} \\
\text { (table 2) }\end{array}$} & \multirow[b]{2}{*}{$\begin{array}{l}\text { Aquifer within which } \\
\text { well is completed }\end{array}$} & \multirow[b]{2}{*}{$\begin{array}{c}\text { Confining } \\
\text { unit that } \\
\text { overlies } \\
\text { aquifer in } \\
\text { which well } \\
\text { is completed }\end{array}$} & \multirow[b]{2}{*}{$\begin{array}{l}\text { Basin in } \\
\text { which well } \\
\text { is located } \\
\text { (figure 1) }\end{array}$} & \multicolumn{5}{|c|}{ Median recharge } & \multicolumn{3}{|c|}{ Leakage } \\
\hline & & & & & $\begin{array}{l}\text { Average } \\
\text { recharge } \\
\text { based on } \\
\text { precipitatio } \\
\text { n method at } \\
\text { well sites }\end{array}$ & $\begin{array}{c}\text { Median } \\
\text { recharge based } \\
\text { on streamflow } \\
\text { recession } \\
\text { displacements } \\
\text { at well sites } \\
\text { 3 }\end{array}$ & $\begin{array}{l}\text { Median } \\
\text { recharge based } \\
\text { on ground- } \\
\text { water level } \\
\text { fluctuations at } \\
\text { well sites }\end{array}$ & $\begin{array}{l}\text { Recharge } \\
\text { based on age } \\
\text { dating of } \\
\text { shallow } \\
\text { ground water } \\
\text { at well sites }\end{array}$ & $\begin{array}{c}\text { Minimal } \\
\text { recharge based } \\
\text { on watershed } \\
\text { characteristics } \\
\text { at well sites }\end{array}$ & $\begin{array}{l}\text { Based on } \\
\text { ground- } \\
\text { water level } \\
\text { fluctuations }\end{array}$ & $\begin{array}{l}\text { Prairie du } \\
\text { Chien- } \\
\text { Jordan } \\
\text { aquifer } \\
\text { only }^{5}\end{array}$ & $\begin{array}{c}\text { Based on } \\
\text { vertical } \\
\text { hydraulic } \\
\text { gradients }\end{array}$ \\
\hline 1 & 1 & $\begin{array}{l}\text { Unconfined glacial sand } \\
\text { and gravel }\end{array}$ & NA & nd & 8.2 & -- & 7.1 & -- & $1.5-<2.5$ & -- & -- & -- \\
\hline 2 & 2 & $\begin{array}{l}\text { Unconfined glacial sand } \\
\text { and gravel }\end{array}$ & NA & $\begin{array}{l}\text { Vermillion } \\
\text { River }\end{array}$ & 8.3 & $7.1(1985-96)$ & $8.3(1985-96)$ & -- & $1.5-<2.5$ & -- & -- & -- \\
\hline \multirow[t]{2}{*}{3} & 3 & $\begin{array}{l}\text { Unconfined glacial sand } \\
\text { and gravel }\end{array}$ & NA & nd & 8.2 & -- & 5.2 & -- & $1.5-<2.5$ & -- & -- & -- \\
\hline & $3 \mathrm{~B}$ & $\begin{array}{l}\text { Confined glacial sand } \\
\text { and gravel }\end{array}$ & Glacial-drift & & -- & -- & -- & -- & -- & -- & $0-<4.0$ & $5.3 \times 10^{-5}$ \\
\hline 4 & 4 & $\begin{array}{l}\text { Unconfined glacial sand } \\
\text { and gravel }\end{array}$ & NA & nd & 8.2 & -- & 10.8 & -- & $1.5-<2.5$ & -- & -- & -- \\
\hline 5 & 5 & $\begin{array}{l}\text { Unconfined glacial sand } \\
\text { and gravel }\end{array}$ & NA & Rum River & 8.0 & $5.5(1981-98)$ & $9.2(1981-98)$ & -- & $1.5-<2.5$ & -- & -- & -- \\
\hline \multirow[t]{2}{*}{6} & 6 & $\begin{array}{l}\text { Unconfined glacial sand } \\
\text { and gravel }\end{array}$ & NA & nd & 8.3 & -- & 6.3 & -- & $1.5-<2.5$ & -- & -- & -- \\
\hline & $6 \mathrm{~A}$ & Prairie du Chien-Jordan & Glacial-drift & & -- & -- & -- & -- & -- & -- & $0-<4.0$ & $6.4 \times 10^{-2}$ \\
\hline 7 & 7 & $\begin{array}{l}\text { Unconfined glacial sand } \\
\text { and gravel }\end{array}$ & NA & nd & 8.3 & -- & 8.3 & -- & $>2.5$ & -- & -- & -- \\
\hline 8 & 8 & $\begin{array}{l}\text { Unconfined glacial sand } \\
\text { and gravel }\end{array}$ & NA & $\begin{array}{l}\text { Vermillion } \\
\text { River }\end{array}$ & 8.1 & 5.7 & 6.5 & -- & $1.5-<2.5$ & -- & -- & -- \\
\hline 9 & 9 & $\begin{array}{l}\text { Unconfined glacial sand } \\
\text { and gravel }\end{array}$ & NA & nd & 7.7 & -- & 12.2 & -- & $>2.5$ & -- & -- & -- \\
\hline 10 & 10 & $\begin{array}{l}\text { Unconfined glacial sand } \\
\text { and gravel }\end{array}$ & NA & nd & 8.1 & -- & 8.4 & -- & $1.5-<2.5$ & -- & -- & -- \\
\hline 11 & 11 & $\begin{array}{l}\text { Unconfined glacial sand } \\
\text { and gravel }\end{array}$ & NA & nd & 8.2 & -- & 10.7 & -- & $1.5-<2.5$ & -- & -- & -- \\
\hline 12 & $12 \mathrm{~A}$ & Mt. Simon-Hinckley & Eau Claire & nd & -- & -- & -- & -- & -- & -- & -- & $1.2 \times 10^{-3}$ \\
\hline 13 & $13 \mathrm{~A}$ & Ironton-Galesville & Franconia & nd & -- & -- & -- & -- & -- & -- & -- & $3.6 \times 10^{-4}$ \\
\hline \multirow[t]{2}{*}{14} & $14 \mathrm{~A}$ & Ironton-Galesville & Franconia & nd & -- & -- & -- & -- & -- & -- & $0-<4.0$ & $2.1 \times 10^{-4}$ \\
\hline & $14 \mathrm{~B}$ & Mt. Simon-Hinckley & Eau Claire & nd & & & & & & & & $3.2 \times 10^{-3}$ \\
\hline 15 & 15 & $\begin{array}{l}\text { Confined glacial sand } \\
\text { and gravel }\end{array}$ & Glacial-drift & nd & -- & -- & -- & -- & -- & $7.4 \times 10^{-3}$ & -- & -- \\
\hline
\end{tabular}


Table 4.--Comparison of recharge and leakage estimates based on multiple methods in the Twin Cities metropolitan area, Minnesota (Continued).

(All values reported in units in inches per year; <, less than; >, greater than; NA, not applicable; --, no data; nd, not determined)

\begin{tabular}{|c|c|c|c|c|c|c|c|c|c|c|c|c|}
\hline \multirow[b]{2}{*}{$\begin{array}{l}\text { Well site } \\
\text { number }\end{array}$} & \multirow[b]{2}{*}{$\begin{array}{c}\text { Well } \\
\text { identifier }^{2} \\
\text { (table 2) }\end{array}$} & \multirow[b]{2}{*}{$\begin{array}{l}\text { Aquifer within which } \\
\text { well is completed }\end{array}$} & \multirow[b]{2}{*}{$\begin{array}{c}\text { Confining } \\
\text { unit that } \\
\text { overlies } \\
\text { aquifer in } \\
\text { which well } \\
\text { is completed }\end{array}$} & \multirow[b]{2}{*}{$\begin{array}{l}\text { Basin in } \\
\text { which well } \\
\text { is located } \\
\text { (figure 1) }\end{array}$} & \multicolumn{5}{|c|}{ Median recharge } & \multicolumn{3}{|c|}{ Leakage } \\
\hline & & & & & $\begin{array}{l}\text { Average } \\
\text { recharge } \\
\text { based on } \\
\text { precipitatio } \\
\text { n method at } \\
\text { well sites }\end{array}$ & $\begin{array}{c}\text { Median } \\
\text { recharge based } \\
\text { on streamflow } \\
\text { recession } \\
\text { displacements } \\
\text { at well sites }{ }^{3}\end{array}$ & $\begin{array}{l}\text { Median } \\
\text { recharge based } \\
\text { on ground- } \\
\text { water level } \\
\text { fluctuations at } \\
\text { well sites }\end{array}$ & $\begin{array}{c}\text { Recharge } \\
\text { based on age } \\
\text { dating of } \\
\text { shallow } \\
\text { ground water } \\
\text { at well sites }\end{array}$ & $\begin{array}{l}\text { Minimal } \\
\text { recharge based } \\
\text { on watershed } \\
\text { characteristics } \\
\text { at well sites }\end{array}$ & $\begin{array}{l}\text { Based on } \\
\text { ground- } \\
\text { water level } \\
\text { fluctuations }\end{array}$ & $\begin{array}{l}\text { Prairie du } \\
\text { Chien- } \\
\text { Jordan } \\
\text { aquifer } \\
\text { only }^{5}\end{array}$ & $\begin{array}{l}\text { Based on } \\
\text { vertical } \\
\text { hydraulic } \\
\text { gradients }\end{array}$ \\
\hline \multirow{4}{*}{16} & $15 \mathrm{~A}$ & $\begin{array}{l}\text { Confined glacial sand } \\
\text { and gravel }\end{array}$ & Glacial-drift & nd & & & & & & $4.7 \times 10^{-3}$ & -- & -- \\
\hline & $15 \mathrm{~B}$ & Ironton-Galesville & Franconia & nd & & & & & & $8.0 \times 10^{-3}$ & -- & $4.6 \times 10^{-5}$ \\
\hline & $16 \mathrm{~A}$ & St. Peter & Glenwood & nd & -- & -- & -- & -- & -- & -- & $0-<4.0$ & $9.3 \times 10^{-3}$ \\
\hline & $16 \mathrm{~B}$ & Prairie du Chien-Jordan & $\begin{array}{l}\text { Basal St. } \\
\text { Peter }\end{array}$ & & & & & & & & & $1.1 \times 10^{-1}$ \\
\hline 17 & 17 & Prairie du Chien-Jordan & Glacial-drift & nd & -- & -- & -- & -- & -- & $1.0 \times 10^{-2}$ & -- & -- \\
\hline 18 & 18 & Prairie du Chien-Jordan & Glacial-drift & nd & -- & -- & -- & -- & -- & $5.30 \times 10^{-3}$ & $0-<4.0$ & -- \\
\hline 19 & 19 & Prairie du Chien-Jordan & Glacial-drift & nd & -- & -- & -- & -- & -- & $7.3 \times 10^{-3}$ & $0-<4.0$ & -- \\
\hline 20 & 20 & Prairie du Chien-Jordan & Glacial-drift & nd & -- & -- & -- & -- & -- & $4.4 \times 10^{-3}$ & $4-<8.0$ & -- \\
\hline 21 & 21 & Prairie du Chien-Jordan & Glacial-drift & nd & -- & -- & -- & -- & -- & $9.1 \times 10^{-3}$ & $0-<4.0$ & -- \\
\hline 22 & 22 & Prairie du Chien-Jordan & Glacial-drift & nd & -- & -- & -- & -- & -- & $1.1 \times 10^{-2}$ & $0-<4.0$ & -- \\
\hline 23 & 23 & Prairie du Chien-Jordan & Glacial-drift & nd & -- & -- & -- & -- & -- & $4.9 \times 10^{-3}$ & $0-<4.0$ & -- \\
\hline 24 & 24 & $\begin{array}{l}\text { Confined glacial sand } \\
\text { and gravel }\end{array}$ & Glacial-drift & nd & -- & -- & -- & -- & -- & $3.20 \times 10^{-3}$ & $8-<12$ & -- \\
\hline 25 & 25 & $\begin{array}{l}\text { Unconfined glacial sand } \\
\text { and gravel }\end{array}$ & -- & nd & 7.8 & -- & -- & 8.8 & $>2.5$ & -- & -- & -- \\
\hline
\end{tabular}

${ }^{1}$ See figure 1 .

${ }^{2}$ See figure 2 .

${ }^{3}$ Determined for entire period of record indicated in table 1 unless otherwise noted.

${ }^{4}$ Determined for entire period of record indicated in table 3 unless otherwise noted

${ }^{5}$ based on vertical hydraulic gradients (from Larson-Hidgem and others, 1975. 
method. This difference indicates variable rates of recharge in the basin that resulted in a smaller average estimate for the basin as a whole than the site-specific estimate for well 5. Minimal ground-water recharge estimated by the watershed characteristics method for the area surrounding well 5 ranged from 1.5 to less than 2.5 in./yr.

Glacial drift in the upstream onehalf of the Rum River Basin mostly consists of silty and clayey lake deposits, in contrast to the glacial drift in the lower one-half, which consists mostly of sandy outwash (Ericson and others, 1974). Based on glacial geologic features of the basin, the permeability of surficial materials would be lower in the upstream one-half of the basin than in the downstream onehalf. Variable rates of recharge in the basin (smaller in upstream one-half), therefore, would likely result from these differences in surficial geologic deposits.

\section{METHODS TO ESTIMATE LEAKAGE}

Leakage rates estimated by the hydraulic-gradient method varied over 4 orders of magnitude, but the rates estimated by the ground-water level fluctuation method only varied within 1 order of magnitude. The rates generally were smaller for the vertical-hydraulic gradient method (from $4.6 \times 10^{-5}-1.1 \times 10^{-1}$ in./yr; fig. 9) than for the ground-water level fluctuation method $\left(3.2 \times 10^{-3}-1.1 \times 10^{-2} \mathrm{in} . / \mathrm{yr}\right.$; fig. $8)$. Estimates of leakage rates at site 15 , where both methods were applied, differed by 2 orders of magnitude $\left(4.6 \times 10^{-5} \mathrm{in} . / \mathrm{yr}\right.$ based on the verticalhydraulic gradient method and $7.4 \times 10^{-3} \mathrm{in}$./yr based on the groundwater level fluctuation method) (table 4).

The estimates of leakage depend on assumed values of hydraulic properties of aquifers and confining units. In the case of the ground-water level fluctuation method, the estimates are sensitive to the storage coefficient of the aquifers, and in the case of the vertical-hydraulic gradient method, the estimates are sensitive to the vertical-hydraulic conductivity of confining units that overlie the aquifers of interest. The values of these hydraulic properties used in this study are considered accurate to within 2-3 orders of magnitude. The estimates of leakage by these methods, therefore, also are considered accurate to within these same limits.

Estimates of leakage rates to the Prairie du Chien-Jordan aquifer based on application of the Darcy flow equation to vertical-hydraulic gradients, although predominantly less than $4.0 \mathrm{in} . / \mathrm{yr}$, were locally as great as 12 in./yr (fig. 10). These estimates indicate greater rates of leakage than previously discussed site-specific estimates. The site-specific estimates were made for well sites located in areas where the estimates of leakage to the Prairie du Chien-Jordan aquifer were mapped as less than $4.0 \mathrm{in} . / \mathrm{yr}$, the smallest range mapped for the aquifer (fig. 10).

\section{Some of the disparities between} the areal and site-specific estimates of leakage rates are attributable to differences in assumed vertical-hydraulic conductivities of glacial-drift confining units. The site-specific leakage estimates are based on an assumed vertical-hydraulic conductivity value of $1.0 \times 10^{-6} \mathrm{ft} / \mathrm{d}$. The areal leakage estimates are based on hydraulic conductivity values that range from $1.8 \times 10^{-3}$ to $2.4 \times 10^{-3} \mathrm{ft} / \mathrm{d}$, which are values that were adjusted where necessary to yield a mean leakage rate of $5.24 \mathrm{in}$./yr. The hydraulic gradients used to estimate areal leakage rates were based on area-wide, historical ground-water level data from different periods, in contrast to the hydraulic gradients used to estimate site-specific leakage rates, which were based on synoptic ground-water level measurements at nested well sites.

\section{LIMITATIONS}

The precipitation method was the simplest, but also the least certain in terms of the confidence level associated with the results of the method. Precipitation data required for this method were readily available. The confidence level associated with this method potentially could improve by additional recharge studies if the results of such studies could more accurately determine the proportionality factors.

The streamflow-recession displacement method was limited in its application to basins with available streamflow records. Automation of the method by the program RORA made its application easy. Halford and Mayer (2000), however, questioned the validity of critical assumptions that underlie use of the program RORA. Specifically, they challenged the following three assumptions: (1) that the recession index of the contributing aquifer can be determined from streamflow data; (2) that periods of exclusive ground-water discharge can be identified; and (3) that stream discharge responds instantaneously to recharge. Rutledge (2000), in a recently published report about RORA that addressed uncertainties associated with its underlying assumptions discussed by Halford and Mayer (2000), updated considerations regarding use of the program. This updated information was applied in this present study, which regards use of the program as a valid method to estimate recharge.

Continued operation of currently active streamflow-gaging stations and installation of additional stations in ungaged basins will benefit future studies that use the streamflow-recession displacement method. Augmentation of available streamflow records in data bases maintained by the USGS and Metropolitan Council will make possible the use of this method to 
update and refine the estimates of recharge in the study area.

The ground-water level fluctuation method is well documented and can be applied to wells with ground-water level data collected on at least a monthly basis. The accuracy of this method is enhanced because of its insensitivity to the mechanisms by which recharge and leakage enter the aquifer of interest. The accuracy of this method is limited by the uncertainty in the assumed values of specific yield and storage coefficient and by the extent to which underlying assumptions of the method are valid. Continued collection of ground-water level data from wells will provide future opportunities to update and refine estimates of recharge and leakage based on this method.

The age dating of shallow ground water method required collection of field data. In urban environments, such as the study area, age dating of shallow ground water with the environmental tracer $\mathrm{SF}_{6}$ can be invali- dated because of contamination by volatile organic compounds. In this study, the age-dating method for 5 of 7 ground-water samples was unsuccessful because of methane contamination. Although two samples did not have methane contamination, the samples did have non-atmospheric sources of $\mathrm{SF}_{6}$ that complicated interpretation of the data.

The watershed characteristics method required complex statistical analyses of detailed geologic data and long-term streamflow records. The results of the method represent standardized, conservative estimates of minimal ground-water recharge that are associated with February low-flow streamflow characteristics and the areal extent of hydrogeologic units. The advantage of standardization is that the results are more independent of time and scale than the other methods. Collection of low-flow streamflow data will benefit future applications of this method. The major limitation of the method is the lack of documentation that explains the underlying assumptions and methodology.

Analyses of vertical-hydraulic gradients based on application of the Darcy flow equation to estimate leakage to confined aquifers was a simple method to apply where the required hydrogeologic data were available. Ideally, this method is applied at nested well sites where sufficient ground-water level measurements are available to define vertical-hydraulic gradients between aquifers of interest. Vertical-hydraulic conductivities must be assumed for confining units that separate these aquifers. The accuracy of the leakage estimates generally is limited by the accuracy in the determination of the vertical-hydraulic conductivities of the confining units. Additional studies that investigate the hydraulic properties of confining units in the study area would improve estimates of leakage by this method.

\section{SUMMARY}

Water-resource managers in the Twin Cities metropolitan area consider long-term depletion of ground-water supplies from economic development and population growth an important water-resource issue. Recharge to unconfined aquifers and leakage to confined aquifers were estimated in the seven-county Twin Cities metropolitan area of Minnesota. Information about recharge and leakage to aquifers will enhance the formulation of management plans to address this issue. Recharge is defined as the addition of water to unconfined aquifers and leakage to confined aquifers.

Multiple methods were used to quantitatively estimate recharge and leakage. These methods include analyses of: (1) precipitation data from 150 rain gages; (2) streamflow hydrographs for 7 basins; (3) ground-water hydrographs for 27 wells; (4) concentrations of the environmental tracer, sulfur hexafluoride $\left(\mathrm{SF}_{6}\right)$, in ground-water samples from nested monitoring wells at 1 site; (5) hydrologic characteristics of 101 watersheds; and (6) vertical-hydraulic gradients at seven nested monitoring well sites. A qualitative assessment of recharge and leakage was made on the basis of permeability of land-surface materials and subcrops of principal bedrock aquifer, respectively.
Impervious land areas in the Minneapolis and St. Paul downtown areas and developments in surrounding suburbs indicate little or no recharge potential. Surficial sand and gravel areas, which correlate with outwash deposits in Anoka, Dakota, and Washington Counties and with outwash and terrace deposits along the Minnesota River Valley in Carver and Scott Counties, indicate large recharge potential.

Mean recharge estimated from precipitation for the period of record 1961-90 ranged from 7.7 to $8.3 \mathrm{in./yr}$. These estimates apply to portions of the study area where surficial sand and gravel are present.

Annual recharge estimated from streamflow-recession displacements for seven basins during 1961-98 ranged from ranged from $0.5 \mathrm{in./yr}$ (Elm Creek Basin-1988) to 13.5 in./yr. (Rum River Basin-1986). The median recharge for each year for period of record in the basins ranged from 1.2 to $12.2 \mathrm{in}$./yr. The median recharge, as a percentage of precipitation, for each year of the period of record ranged from 5 to 34 percent.

Annual recharge estimated from ground-water level fluctuations for 11 wells during 1971-99 ranged from 1.6 to $35.3 \mathrm{in./yr}$. Estimates that exceed $20 \mathrm{in} . / \mathrm{yr}$ are unreasonably large. The median recharge for each year of the period of 
record for the wells ranged from 4.5 to $13.6 \mathrm{in./yr}$. The median recharge, as a percentage of precipitation, for each year of the period of record ranged from 18 to 42 percent.

Recharge estimated for a nested well site by age-dating of shallow ground water $\mathrm{SF}_{6}$ was $8.8 \mathrm{in} . / \mathrm{yr}$. The method was conducted at two other nested well sites, but methane contamination of the ground-water samples precluded application of the method at those sites.

Minimal ground-water recharge estimated by the watershed characteristics method ranged from 0.1 to less than 2.5 in./yr in most of the study area. The largest rates correlated with areas of surficial sand and gravel. In small portions of the southeastern part of the study area, estimated rates were as large as $5.6 \mathrm{in./yr}$ and less than $0.1 \mathrm{in./yr}$.

For confined glacial drift and bedrock aquifers, estimated leakage rates, which were less than $1 \mathrm{in} . / \mathrm{yr}$, varied as much as 4 orders of magnitude. Leakage rates estimated by the ground-water level fluctuation method ranged from $3.2 \times 10^{-3}$ to $1.1 \times 10^{-2} \mathrm{in}$./yr for confined bedrock and glacial drift aquifers. Leakage rates estimated by the verticalhydraulic gradient method ranged from $4.6 \times 10^{-5}$ to $1.1 \times 10^{-}$ 1 in./yr. The rates estimated by these two methods are site specific to the vicinity of the analyzed wells. Leakage rates to the Prairie du Chien-Jordan aquifer from a previous study—also estimated by the vertical-hydraulic gradient method, but on a small-scale basis-ranged from 0 to less than $12 \mathrm{in./yr}$ in about 75 percent of the study area.
Recharge rates estimated by the different methods generally varied less than $10 \mathrm{in} . / \mathrm{yr}$. The estimated rates generally were largest for the precipitation, ground-water level fluctuation, and age dating of shallow ground-water methods, slightly smaller for the streamflow-recession displacement method, and smallest for the watershed characteristics method.

The precipitation method was the simplest to apply, but was the least certain in terms of the confidence level. The streamflow-recession displacement method, which was done by automated analyses, was easy to apply. Use of this method was limited, however, to basins with long-term, continuous streamflow records. The ground-water level fluctuation method also was easy to apply, but time-consuming because of the required manual graphical analyses of hydrographs. The accuracy of this method is enhanced because of its insensitivity to the mechanisms by which recharge and leakage enter an aquifer, but is limited by the uncertainty of the assumed values of specific yield and storage coefficient. The age dating of shallow ground water method required collection of field data. Application of this method was unsuccessful at two of three sites where the method was used because of methane contamination. The watershed characteristics method required complex statistical analyses of detailed geologic data and long-term streamflow records. The advantage of this method is that the results are more independent of time and scale than the other methods.

\section{REFERENCES}

Athavale, R.N., and Rangarajan, R., 1997, Rainfall recharge relationship in four main geological provinces of India: Journal of Applied Hydrology, v. 10, no. 3-4, p. 54-59.

Balaban, N.H., 1989, Geologic atlas, Hennepin County, Minnesota: Minnesota Geological Survey, County Atlas Series, Map C-4, 8 plates, scale 1:100,000.

Balaban, N.H., and Hobbs, H.C., 1990, Geologic atlas, Dakota County, Minnesota: Minnesota Geological Survey, County Atlas Series, Map C-6, 9 plates, scale 1:100,000.

Balaban, N.H., and McSwiggen, P.L., 1982, Geologic atlas, Scott County, Minnesota: Minnesota Geological Survey, County Atlas Series, Map C-1, 6 plates, scale 1:100,000.

Bauer, H.H., and Mastin, M.C., 1997, Recharge from precipitation in three small glacial-till-mantled catchments in the Puget Sound Lowland, Washington: U.S. Geological Survey WaterResources Investigations Report 96-4219, 119 p.

Busenberg, E., and Plummer, L.N., 2000 , Dating young ground water with sulfur hexafluoride: Natural and anthropogenic sources of sulfur hexafluoride: Water Resources Research, v. 36, no. 10, p. 3011-3030.

Daniel, J.F., 1976, Estimating ground water evapotranspiration from streamflow records: Water Resources Research, v. 12, no. 3, p. 360-364.

Delin, G.N., Healy, R.W., Landon, M.K., and Bohlke, J.K., 2000,
Effects of topography and soil properties on recharge at two sites in an agricultural field: Journal of the American Water Resources Association, v. 36, no. 6, p. 1401-1416.

Delin, G.N, Landon, M.K., Lamb, J.A., and Anderson, J.L., 1994, Characterization of the hydrogeology and water quality at the management systems evaluation area near Princeton, Minnesota, 1991-92: U.S. Geological Survey WaterResources Investigations Report 94-4149, 54 p.

Delin, G.N., and Woodward, D.G., 1982, Hydrogeologic setting and the potentiometric surfaces of the regional aquifers of the Hollandale Embayment, southeastern Minnesota, 1970-80: U.S. Geological Survey Water- 
Supply Paper 2219, 56 p.

Ericson, D.W., Lindholm, G.F., and

Helgesen, J.O., 1974, Water

resources of the Rum River watershed, east-central Minnesota: U.S. Geological Survey Hydrologic Investigations Atlas HA-509, 3 sheets, scale $1: 250,000$.

Fetter, C.W., 1988, Applied Hydrogeology ( $2 \mathrm{~d}$ ed.): Columbus, Ohio, Merrill Publishing Company, $488 \mathrm{p}$.

Freeze, R.A., and Cherry, J.A., 1979, Groundwater: Englewood Cliffs, New Jersey, PrenticeHall, Inc., 604 p.

Halford, K.J., and Mayer, G.C., 2000, Problems associated with estimating ground-water discharge and recharge from stream-discharge records: Ground Water, v. 38, no. 3, p. 331-342.

Hantush, M.S., 1956, Analysis of data from pumping tests in leaky aquifers: Transactions of American Geophysical Union, v. 37, no. 6, p. 702-714.

Heath, R.C., 1983, Basic groundwater hydrology: U.S. Geological Survey Water Supply Paper 2220, 84 p.

Kudelin, B.I., 1960, Principles of regional assessment of natural ground-water resources: MGU Publication, Moscow, 344 p. (Russian).

Larson-Higdem, D., Larson, S.P., and Norvitch, R.F., 1975, Configuration of the water table and distribution of downward leakage to the Prairie du Chien-Jordan aquifer in the MinneapolisSaint Paul metropolitan area, Minnesota: U.S. Geological Survey Open-File Report 75342, 29 p.

Law, C.S., Watson, A.J., and Liddicoat, M.I., 1994, Automated vacuum analysis of sulfur hexafluoride in seawater-Derivation of the atmospheric trend
(1979-1993) and potential as a transient tracer: Marine Chemistry, v. 48, p. 57-69.

Lindskov, K.L., 1977, Low-flow characteristics of Minnesota streams: U.S. Geological Survey Open-File Report 77-48, $197 \mathrm{p}$.

McWhorter, D., and Sunada, D.K., 1977, Ground-water hydrology and hydraulics, WaterResources Publications, Fort Collins, Colorado.

Metropolitan Council, 2000, Metropolitan Council: accessed July 17, 2000 at URL: www.metrocouncil.org.

Minnesota Department of Natural Resources, 2000, Minnesota Department of Natural Resources: accessed July 15, 2000 at URL:

www.dnr.state.mn.us.

Meyer, G.N., and Lusardi, B.A., 2000, Surficial geology of the St. Paul 30 x 60 minute quadrangle: Minnesota Geological Survey, M-106, scale $1: 100,000$.

Meyer, G.N., and Patterson, C.J., 1999, Surficial geology of the Anoka 30 x 60 minute quadrangle: Minnesota Geological Survey, M-97, scale 1:100,000.

Meyer, G.N., and Swanson, L., 1992, Geologic atlas, Ramsey County, Minnesota: Minnesota Geological Survey, County Atlas Series Map C-7, 10 plates, scale 1:100,000.

Mossler, J.H., and Tipping, R.G., 2000, Bedrock geology and structure of the seven-county Twin Cities metropolitan area, Minnesota: Minnesota Geological Survey, Miscellaneous Map series, Map M-104.

Mroczek, E.K., 1997, Henry's law constants and distribution coefficients of sulfur hexafluoride in water from 25 degrees $\mathrm{C}$ to 230 degrees C: Journal of
Chemical Engineering Data, v. 42, p. 116-119.

Norvitch, R.F., Ross, T.G., and Brietkrietz, A., 1973, Water resources outlook for the Minneapolis-St. Paul metropolitan area: Metropolitan Council of the Twin Cities Area, 219 p.

Patra, P.K., Lal, S., Bubbaraya, B.H., Jackman, C.H., and Rajaratnam, P., 1997, Observed vertical profile of sulphur hexafluoride $\left(\mathrm{SF}_{6}\right)$ and its atmospheric applications: Journal of Geophysical Research, v. 102, no. D7, p. 8855-8859.

Puente, Celso, 1975, Relation of precipitation to annual groundwater recharge in the Edwards aquifer, San Antonio area, Texas: U.S. Geological Survey Open File Report 75-298, 31 p. 1978, Method of estimating natural recharge to the Edwards aquifer in the San Antonio area, Texas: U.S. Geological Survey Water-Resources Investigations 78-10, $34 \mathrm{p}$.

Rasmussen, W.C., and Andreason, G.G., 1959, Hydrologic budget of the Beaver Dam Creek Basin Maryland: U.S. Geological Survey Water-Supply Paper 1472, $106 \mathrm{p}$.

Ravishankara, R.A., Solomon, S., Turnipseed, A.A., and Warren, R.F., 1993, Atmospheric lifetimes of long-lived species: Science, v. 259, p. 194-199.

Reeder, H.O., Wood, W.W., Ehrlich, G.G., and Sun, R.J., 1976, Artificial recharge through a well in fissured carbonate rock, West St. Paul, Minnesota: U.S. Geological Survey Water-Supply Paper 2004, 80 p.

Rorabaugh, M.I., 1964, Estimating changes in bank storage and ground water contribution to streamflow: International Association of Scientific Hydrological Publications 63, p. 432-441. 
Ruhl, J.F., 1999, Hydraulic properties of the Prairie du Chien-Jordan aquifer, Shakopee Mdewakanton Sioux Community, southeastern Minnesota, 1997: U.S. Geological Survey WaterResources Investigations Report 99-4183, 10 p.

Runkel, A.C., and Mossler, J.H., 2001, Hydrostratigraphic and hydraulic characterization of Paleozoic bedrock at nine southeastern Minnesota communities-Research in support of wellhead protection: Minnesota Geological Survey OpenFile Report 01-1, 62 p.

Rutledge, A.T., 1993, Computer programs for describing the recession of ground-water discharge and for estimating mean ground-water recharge and discharge from streamflow records: U.S. Geological Survey Water-Resources Investigations Report 93-4121, 45 p.

1997, Model-estimated groundwater recharge and hydrograph of ground-water discharge to a stream: U.S. Geological Survey Water-Resources Investigations Report 97-4253, 29 p.

2000, Considerations for use of the RORA program to estimate ground-water recharge from streamflow records: U.S. Geological Survey Open-File Report 00-156, 44 p.

Schoenberg, M.E., 1990, Effects of present and projected groundwater withdrawals on the Twin Cities aquifer system, Minnesota: U.S. Geological Survey Water-Resources Investigations Report 90-4001, 165 p. Shmagin, B.A., 1997, The use of a runoff hydrosphere system's structure model as a basis of monitoring and estimation of fresh ground-water natural resources, in Powell, J.D., ed., Third USA/CIS Joint Conference on Environmental Hydrology: Tashkent, Uzbekistan, September 22-27, 1996, (ed. J.D. Powell), p. 107-111.

Shmagin, B.A., Johnston, C.A., and Mooers, H.D., 1998, The systems model of a hydrosphere of the earth and temporal-spatial variability of the river runoff in headwaters of the Mississippi River: Proceedings of the 1998 Annual Conference of the International Association for Mathematical Geology, October 5-9, Isola D'ischia, Italy, p. 438444.

1999, Research of space-time variability of river discharges based on probability modeling in Minnesota, U.S.A.: Russian Academy of Science, Siberian Branch, Geografiia i prirodnye resursy (Journal), no. 1, p. 134143.

Shmagin, B.A., and Kanivetsky, R., 2000, Systems approach for assessment of renewable ground and surface water resources-Minnesota example: Hydrological Science and Technology, v. 16, no. 1-4, p. 25-34.

Snyder, D.T., Morgan, D.S., and McGrath, T.S., 1994, Estimation of ground-water recharge from precipitation, runoff into drywells, and on-site waste-disposal systems in the Portland Basin, Oregon and Washington: U.S. Geological Survey WaterResources Investigations Report 92-4010, 34 p., 1 pl.
Sophocleous, M., 1985, The role of specific yield in ground-water recharge estimations-A numerical study: Ground Water, v. 23, no. 1, p. 52-58.

Strobel, M.L., and Delin, G.N., 1996, Analysis of hydrogeologic properties in the Prairie du Chien-Jordan aquifer, Shakopee Mdewakanton Sioux Community, southeastern Minnesota: U.S. Geological Survey OpenFile Report 96-182, 14 p.

Swanson, L., and Meyer, G.N., 1990, Geologic atlas, Washington County, Minnesota: Minnesota Geological Survey, County Atlas Series, Map C-5, 7 plates, 1:100,000.

Walton, M., Eisenreich, S.J., Holm, N.L., Holm, T.R., Kanivetsky, R., Jirsa, M.A., Lee, H.C., Lauer, J.L., Miller, R.T., Norton, J.L., and Runke, H., 1991, The University of Minnesota aquifer thermal energy storage (ATES) field test facility-System description, aquifer characterization, and results of short-term test cycles: Pacific Northwest Laboratories Report PNL-7220, UC-202, 295 p.

Wanninkhof, R., Ledwell, J.R., and Watson, A.J., 1991, Analysis of sulfur hexafluoride in seawater: Journal of Geophysical Research, v. 96, no. C5, p. 8733-8740.

Winter, T.C., Harvey, J.W., Franke, O.L., and Alley, W.M., 1998, Ground and surface water-A single resource: U.S. Geological Survey Circular 1139, 79 p. 